\title{
Combustion and exergy analysis of multi-component diesel-DME-methanol blends in $\mathrm{HCCl}$ engine
}

\author{
Taghavifar, Hadi; Nemati, Arash; Walther, Jens Honore
}

Published in:

Energy

Link to article, DOI:

https://doi.org/10.1016/j.energy.2019.115951

Publication date:

2019

Document Version

Peer reviewed version

Link back to DTU Orbit

Citation (APA):

Taghavifar, H., Nemati, A., \& Walther, J. H. (2019). Combustion and exergy analysis of multi-component dieselDME-methanol blends in $\mathrm{HCCl}$ engine. Energy, 187, [115951]. https://doi.org/10.1016/j.energy.2019.115951

\section{General rights}

Copyright and moral rights for the publications made accessible in the public portal are retained by the authors and/or other copyright owners and it is a condition of accessing publications that users recognise and abide by the legal requirements associated with these rights.

- Users may download and print one copy of any publication from the public portal for the purpose of private study or research.

- You may not further distribute the material or use it for any profit-making activity or commercial gain

- You may freely distribute the URL identifying the publication in the public portal

If you believe that this document breaches copyright please contact us providing details, and we will remove access to the work immediately and investigate your claim. 


\title{
Combustion and exergy analysis of multi-component diesel- DME-methanol blends in HCCI engine
}

\author{
Hadi Taghavifar ${ }^{1, *}$, Arash Nemati ${ }^{2, *}$, Jens Honore Walther ${ }^{2,3}$ \\ ${ }^{I}$ Department of Mechanical Engineering, Faculty of Engineering, Malayer University, \\ Malayer, Iran \\ ${ }^{2}$ Department of Mechanical Engineering, Technical University of Denmark, Nils Koppels \\ Allé, 2800 Kgs. Lyngby, Denmark \\ ${ }^{3}$ Computational Science and Engineering Laboratory, ETH Zürich, Clausiusstrasse 33, \\ CH-8092 Zürich, Switzerland \\ Email address: $\underline{\text { Haditaghavifar@yahoo.com, Nemati.arash.mech@gmail.com }}$
}

\begin{abstract}
A homogeneous compression ignition (HCCI) engine is taken for numerical investigation on the application of renewable fuels contained blends of methanol and DME with the base diesel fuel, which will be replaced with diesel in different percentages. First, the combustion and engine performance of the engine for two and three-component fuels will be discussed and secondly, the simultaneous effect of EGR in 20\% by mass and engine speed in two blends of having maximum and minimum diesel proportion are compared and examined. The results indicate that the replacement of diesel with 20\% of DME and 30\% by methanol (D50M30DME20) at $1400 \mathrm{rpm}$ generates a greater pressure and accumulated heat $\left(\mathrm{AHR}_{\text {peak }}=330.569 \mathrm{~J}\right)$, whereas D80M20/2000 rpm/EGR20 gives a defective combustive performance with poor engine efficiency (IMEP $=7.21 \mathrm{bar}$ ). The interesting point is that the proposed optimum blend of D50 can achieve the best performance with $\eta_{\text {mech }}=35 \%$ mechanical efficiency. The case of D60M10DME30 though dominates in terms of $\mathrm{RPR}=3.177 \mathrm{bar} / \mathrm{deg}$ and ignition delay $(\mathrm{ID}=4.54 \mathrm{CA})$ that gives the highest
\end{abstract}


exergy performance coefficient $(\mathrm{EPC}=2.063)$ due to its high work and lowest irreversibility.

Keywords: Exergy estimation; CFD Analysis; EGR; HCCI; Multi-component Fuel

\section{Introduction}

It is no more customary to use conventional diesel for CI diesel engines and gasoline for SI engines and engineers through modification and manipulation of fuels composition as emulsions try to come up with enhanced fuel chemistry, which can be responsible for extra power demand and emission control policies in a global scale. In this framework, adding oxygenated fuels as a substitute with diesel sounds like a pragmatic method to achieve a desirable outcome. Emulsification of different fuels is an idea to balance out the ratio of $\mathrm{H}-\mathrm{C}-\mathrm{O}$ in a blended structure of fuel to give the features of interest. Methanol and DME are recognized as alcohols in the form of renewable power source in ICEs [1,2] with diverse features that can be replaced by diesel and control the reactivity of air-fuel mixture. Basically, methanol has a very low cetane number and high ignition delay [3] that can be compensated with the high cetane number of DME. Dimethyl ether (DME) has lowignition temperature [4] that can be easily evaporated with high oxygen content and no CC bonds [5] contributing to smokeless combustion.

HCCI engines are a new generation of engine systems characterized by low NOx and high thermal efficiency [6] inheriting the two main capacity of CI and SI engines where there is no direct controlling mechanism over the ignition timing such as injection or spark timing [7]. The use of blended fuels in this kind of engine is more highlighted in HCCI engines since it gives a leverage to determine the ignition timing by modification of alternative fuel fraction with higher/lower flash point thereby tuning the auto-ignition point [8]. The 
following lists a number of significant studies implemented on the scope of either blended fuels or alternative fuels application in HCCI engines:

Since the operation of HCCI is limited by the ability to control the extreme burning of the homogenous charge and avoiding knock, Li et al. [9] tried to detect the knock phenomenon and cyclic variation within the HCCI engine with a blend prepared by n-butanol and nheptane. The obtained results indicated that the volume fraction of n-butanol can greatly influence the knock as butanol increase lessens the knock probability. As seen, researchers use blending as an outlet to harness the combustion phasing in HCCI ignition mode, for example, Turkcan et al. [10] used a blend of alcohol-gasoline blends in HCCI-DI engine to investigate the impact of second injection timing role on combustion and emission. It was pointed out that increasing methanol fraction would raise the NOx and $\mathrm{P}_{\max }$, while ethanol content increase works oppositely. Zhang et al. [11] in a relevant study considered exergy losses of the auto-ignition process for DME and alcohol blended fuel. The work indicated that the addition of methanol and DME increases the exergy losses by the $\mathrm{H}_{2} \mathrm{O}_{2}$ reaction. Wang et al. [12] considered the combustion of polyoxymethylene dimethyl ether (PODE) in an HCCI engine under various EGRs and charge mass equivalence ratios. A detailed data from the study showed that PODE lean HCCI combustion engenders ultralow NOx and soot content, meanwhile, CO emission decreases with EGR. Yousefzadeh and Jahanian [13] used another alternative fuel in the HCCI engine and proposed CNG to control the combustion phase. Their main findings concluded that hydroxyl radical serves as a robust factor in combustion phasing determination leading to a yet better response time. Nishi et al. [14] were able to set a new HCCI combustion through EGR and engine speed variation. The DME fuel was used in the engine and detailed chemical kinetics was 
incorporated with a single-zone model. It was figured out that higher EGR ratio is demanded to reach the quasi-steady state. Khandal et al. [15] also tried alternative fuels combustion in HCCI engine. These alternative fuels were Honge biodiesel, cottonseed biodiesel, and hydrogen gas. Their results showed that diesel/biodiesel fuel powered HCCI has $67 \%$ lower smoke and $99 \%$ lower NOx at $80 \%$ load, although $3.4 \%$ lower thermal efficiency was reported compared to CI mode. In another recent and relevant study [16], diesel-biodiesel powered HCCI engine is tested that was designed for off-road applications. In brief, the BMEP (brake mean effective pressure) of HCCI without EGR is lower than HCCI with EGR and the BMEP value is the highest for CI engine. Recently, Yao et al. [17] performed a critical review on the diesel-methanol application in CI engines. It was summarized that methanol fumigation can decrease emissions in the diesel engine. While the methanol fumigation features prolonging the ignition delay that is ascribed to chemical and physical properties of methanol. The methanol addition to diesel increases the radical pool and the radicals such as $\mathrm{H}_{2} \mathrm{O}_{2}$ require higher activation energy [18].

Exergy reviews in combustive systems such as engines draw more and more attention due to its potential in identifying the possible agents in reduction of waste energy. In HCCI engines, there are records of exergy study on blended fuels [19-21] where the secondary fuel fraction affects the second law efficiency and heat/work exergy.

From the above review, it can be acknowledged that in HCCI engines it is paramount that the technicians and experts can bring the ignition and combustion phasing under control. So, adopting two alternative fuels with different flammability characteristics, which can substitute diesel by different ratios in a blend seems a logical resolution. Furthermore, EGR introduction in HCCI is practiced to manage the high burning rate of HCCI homogenous 
charge combustion. Moreover, new exergy terms are used to measure the feasibility of methanol and DME blending in diesel in HCCI mode. The effect of addition of methanol and DME on diesel in HCCI mode combustion is investigated from the second law of thermodynamics view. The numerical work is performed by AVL-FIRE CFD code and then the results of engine modeling are employed for exergy analysis within the framework of in-house developed code. This is a rare work on HCCI engine control by varying DME/methanol on base diesel fuel, which gives flexibility over the ignition and combustion of the engine, meanwhile, a detailed exergetic performance is evaluated with advanced parameters as EGR and secondary fuel fraction changed.

\section{Modeling procedure}

\subsection{Engine modeling with CFD methodology}

A TD43 single cylinder, 4-stroke engine operating in lab scale with $600 \mathrm{rpm}$ is selected to simulate an HCCI engine powered by different multi-component renewable fuels (the engine's operational specifications can be found in Table 1). A 1:4 segment of the chamber domain is shown in Fig. 1 with labeled walls in which the flow regime and kinetics of combustion occurs. A meshed view of the chamber at top dead center position consisting of $23 \mathrm{~K}$ cells is also illustrated in Fig. 1 . The boundary conditions of the geometry are the liner wall, moving wall of the piston, head temperatures equal to $475.15,575.15,550.15$ K. 

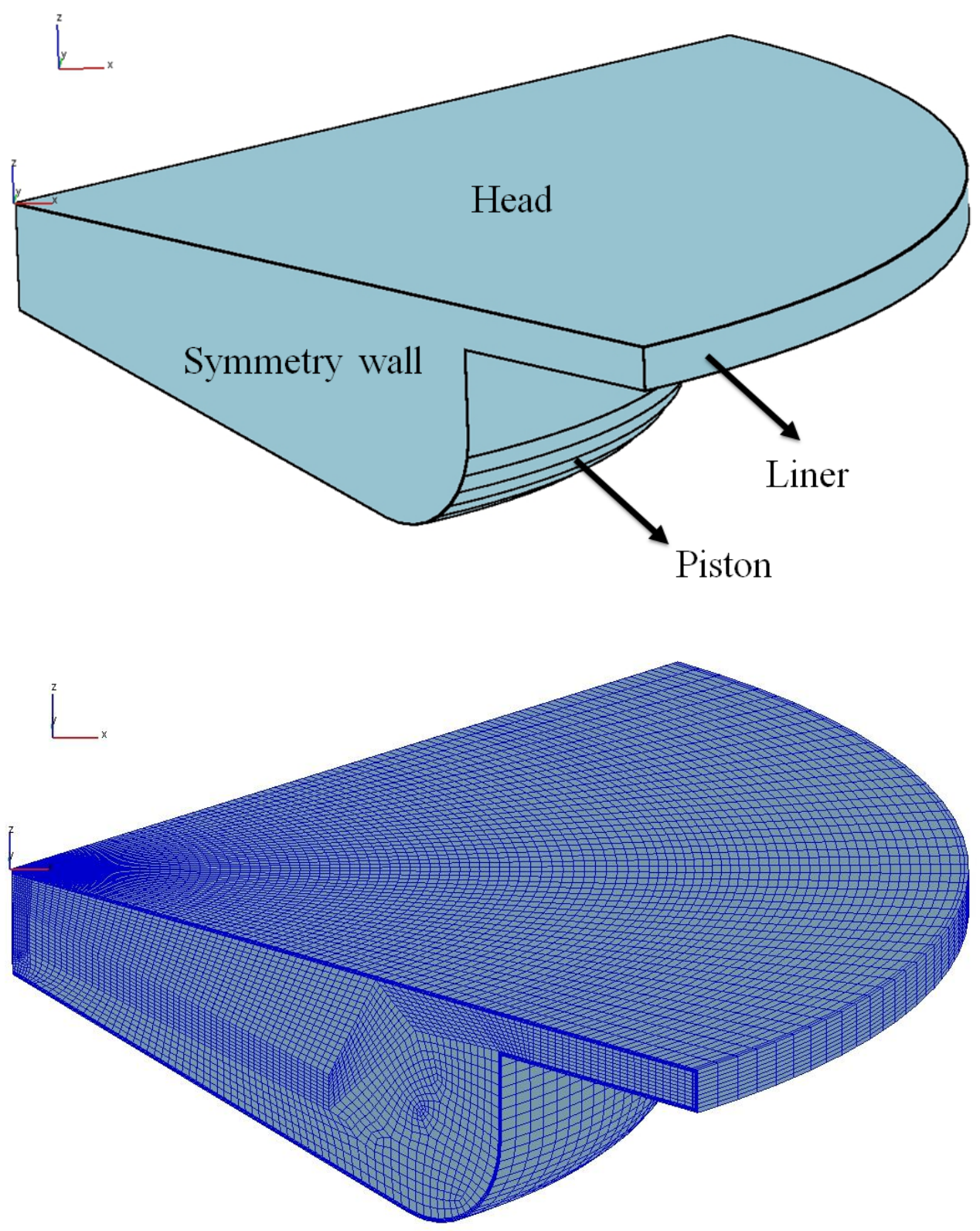

Figure 1. A quarter domain representation of combustion chamber (labeled and meshed)

To implement multi-component fuel combustion, the hydrocarbon fuel is chosen as homogenous multi-component with different percentages from standard species transfer. First, diesel is injected in high ratio and then diesel portion in the blend is reduced and replaced by DME and methanol as alternative fuels. 
Table 1. Engine specification

\begin{tabular}{ll}
\hline Bore $\times$ stroke & $95 \times 82 \mathrm{~mm}$ \\
displacement & $582 \mathrm{~cm} 3 /$ cylinder \\
Compression ratio & $18: 1$ \\
Connecting rod length & $156 \mathrm{~mm}$ \\
\hline
\end{tabular}

Diagram flow of different stages of the study from simulation to exergy computations for the case studies is illustrated in Fig. 2.

Job setup

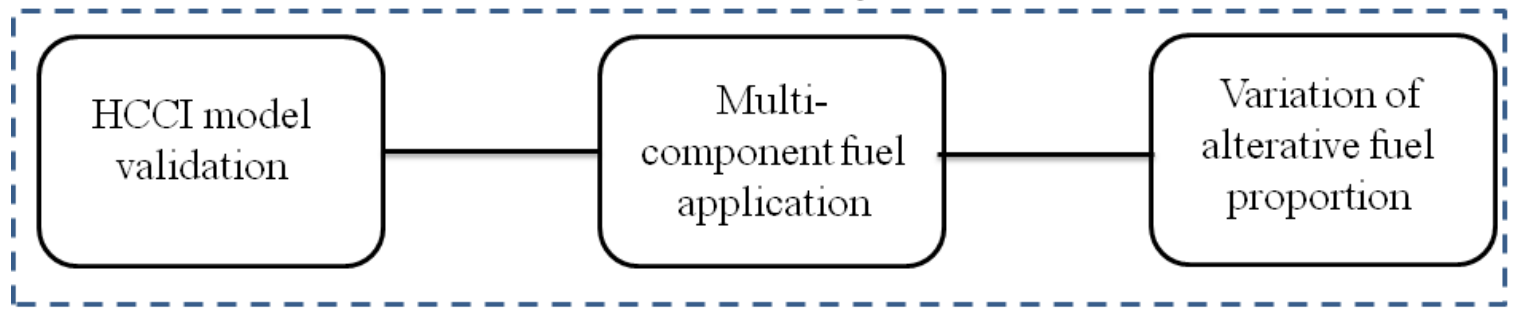

\section{CFD modeling: AVL-FIRE}

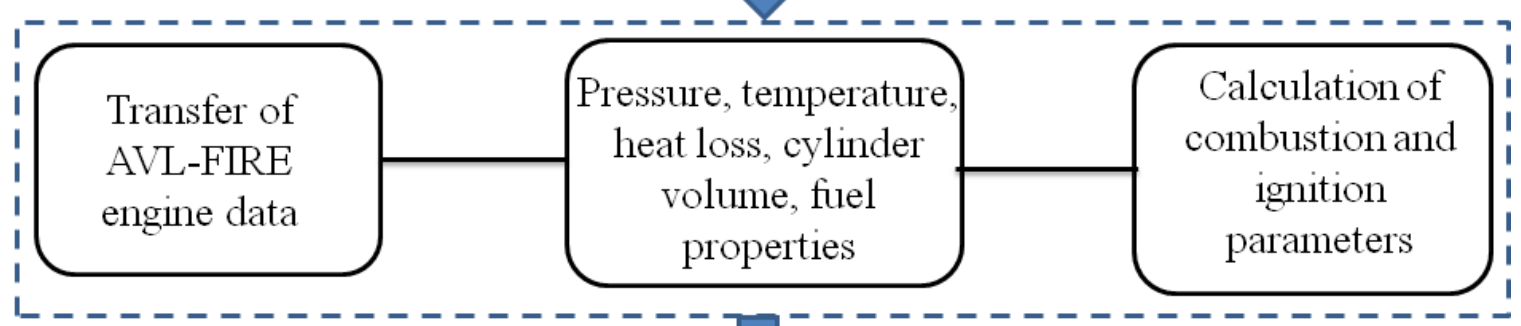

Exergy computation: FORTRAN

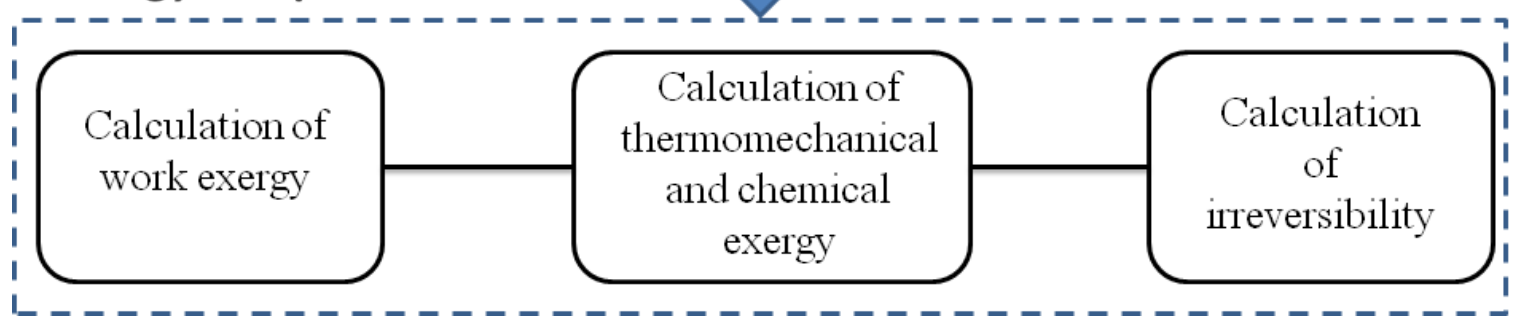

Figure 2. Flow diagram of interactive simulation-exergy concept in HCCI engine

The model is a closed thermodynamic cycle, therein the IVC is at $120 \mathrm{CA}$ and the EVO is happening at $130 \mathrm{CA}$. The time step-size is adjusted based on CA- $\Delta \alpha$ division in different stages of engine stroke. The finest step size happens during the combustion period, where 
detailed chemical and thermodynamic phenomena take place (i.e. $\Delta \alpha=0.2$ ). The k-zeta-f [22] is a suitable strategy for modeling the turbulence that can be used in a near-wall area. The three-zone combustion model of ECFM-3Z [23] gives better results especially for multi-component fuels combustion and is applied for this research. For brevity, the adopted sub-models for species transport, combustion, soot, and NOx are listed in Table 2.

Table 2. Applied sub-models in the modeled engine

\begin{tabular}{llll}
\hline Combustion model & Standard species & NO model & Soot model \\
\hline ECFM-3Z & Multi-component & Extended Zeldovich & Lund flamelet \\
\hline
\end{tabular}

The meshing of the computational domain has taken place in ESE diesel platform, wherein the cells for the spray block are refined to account for two-phase spray combustion. The mean cell size in the meshing is $0.9 \mathrm{~mm}$ with a total number of 23900 cells at TDC. In order to examine the predictability of the model and verify the reliability of simulation setup, the obtained numerical results of the TD43 HCCI engine at $600 \mathrm{rpm}$ for $313 \mathrm{~K}$ diesel fuel are contrasted against measured results [24, 25]. As Fig. 3 shows, the concordance between numerical and experimental data indicates the acceptable accuracy of the model, hence the veracity of the results generated for multi-component fuels is ensured.

(a) 


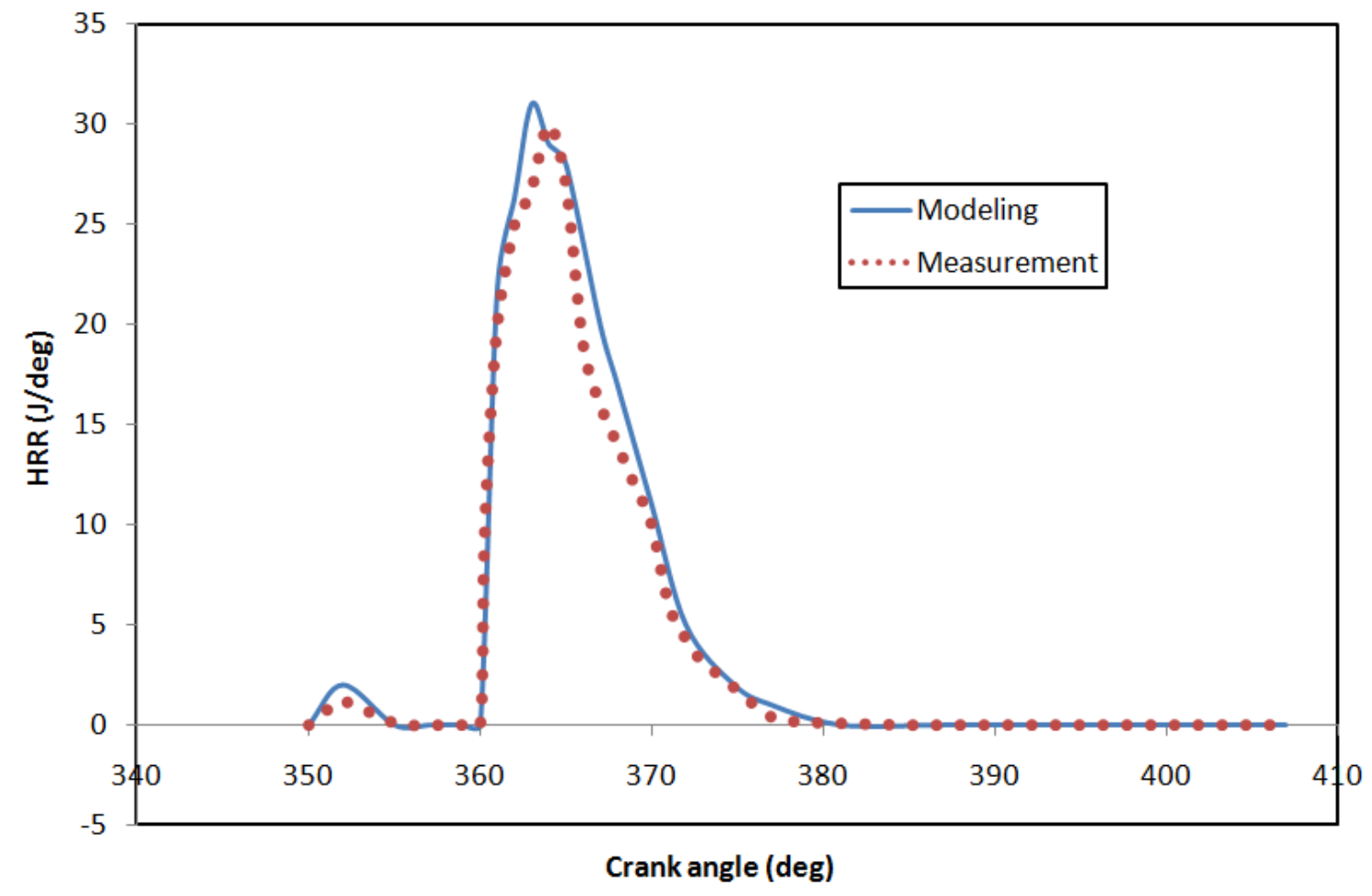

(b)

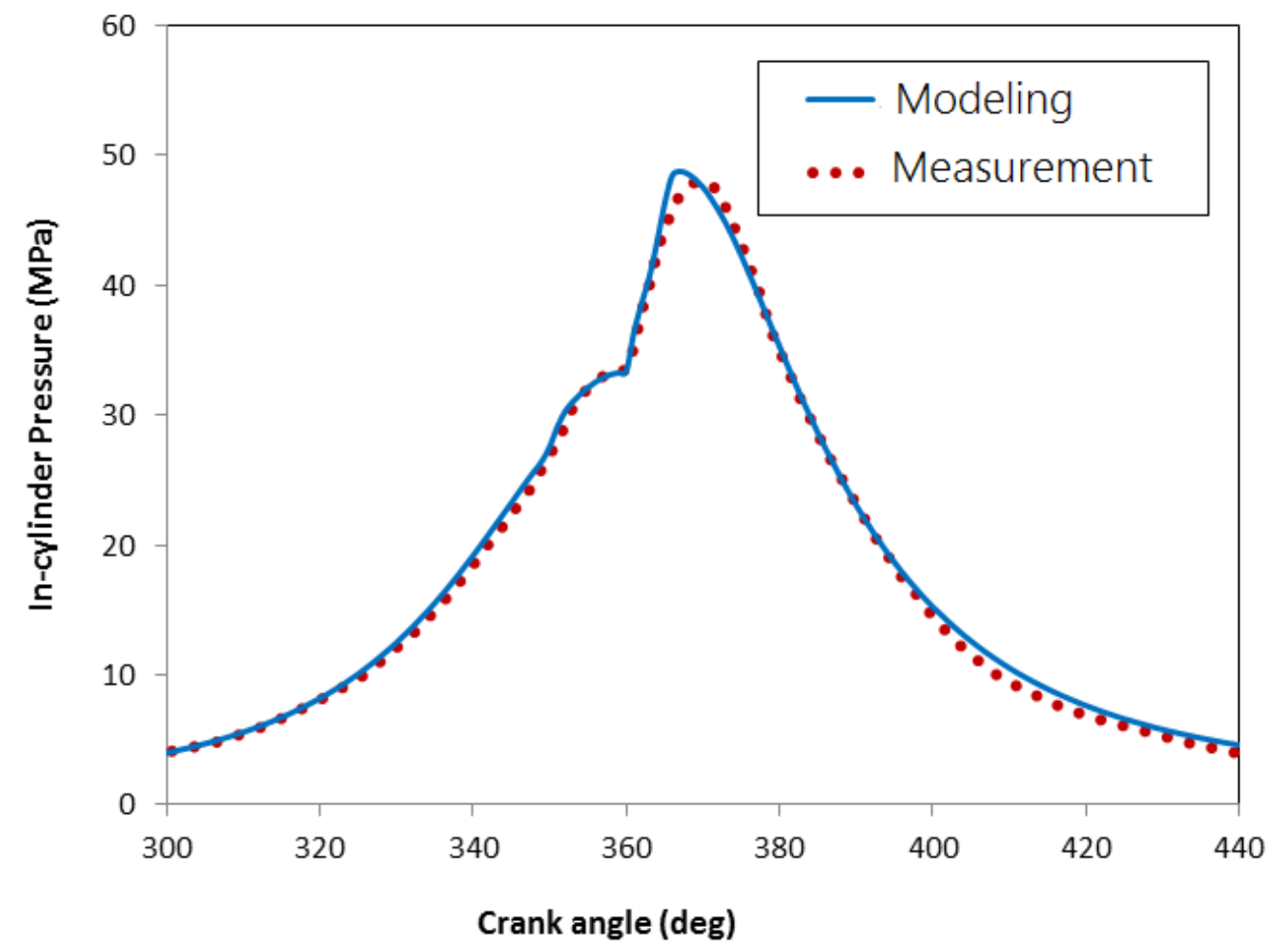


Figure 3. Validation of the results for TD43 HCCI engine (a) HRR diagram, (b) pressure history at $600 \mathrm{rpm}[24,25]$

Zang et al. [26] proposed and experimented apparent ignition delay correlation that is applicable in the simulation of dual-fuel diesel-methanol powered engines.

$$
\tau_{D 80 M 20}=0.002 P^{-2.5}\left(1+\varphi_{\text {methanol }}\right)^{0.7} \varphi_{\text {diesel }}^{-1.04} \exp \left(\frac{4781}{T_{b}}\right)
$$

In addition, Assanis et al. [27] introduced the following equation for diesel fuel:

$\tau=A \phi^{-0.2} P^{-1.02} \exp \left(\frac{2100}{T}\right)$

In the above equations, $\varphi$ is the equivalence ratio, $\mathrm{T}$ is the initial temperature, and $\mathrm{P}$ represents the in-cylinder pressure. By using the above correlations, and the results of diesel and D80M20, the obtained data are gathered in Table 3 at 600 and 2000 rpm engine speeds.

Table 3. Numerical and empirical correlation comparison of ignition delay

\begin{tabular}{|l|l|l|l|l|}
\hline $\begin{array}{l}\text { Engine } \\
\text { speed }(\mathrm{rpm})\end{array}$ & \multicolumn{2}{|l|}{ Diesel ID (CA) } & \multicolumn{2}{l|}{ D80M20 ID (CA) } \\
\hline & Numerical & $\begin{array}{l}\text { Assanis Corr. } \\
{[26]}\end{array}$ & Numerical & $\begin{array}{l}\text { Zang Corr. } \\
{[27]}\end{array}$ \\
\hline 600 & 5.1 & 6.0 & 6.33 & 5.8 \\
\hline 2000 & 3.22 & 4.4 & 3.94 & 4.2 \\
\hline
\end{tabular}

The final pathway for oxidation of DME is described below (the intermediate detailed reactions are not mentioned) [14]:

$\mathrm{CH}_{3} \mathrm{OCH}_{3}+3 \mathrm{O}_{2} \rightarrow 2 \mathrm{CO}_{2}+3 \mathrm{H}_{2} \mathrm{O}$

and the principal detailed reactions of methanol in the low-temperature phase (Eqs. (4-8)) and high-temperature zone are [28]:

$\mathrm{CH}_{3} \mathrm{OH}+\mathrm{OH} \rightarrow \mathrm{CH}_{2} \mathrm{OH}+\mathrm{H}_{2} \mathrm{O}$ 
$\mathrm{CH}_{3} \mathrm{OH}+\mathrm{H} \rightarrow \mathrm{CH}_{2} \mathrm{OH}+\mathrm{H}_{2}$

$\mathrm{CH}_{2} \mathrm{OH}+\mathrm{O}_{2} \rightarrow \mathrm{CH}_{2} \mathrm{O}+\mathrm{H}_{2} \mathrm{O}$

$\mathrm{CH}_{2} \mathrm{O}+\mathrm{OH} \rightarrow \mathrm{HCO}+\mathrm{H}_{2} \mathrm{O}$

$\mathrm{HCO}+\mathrm{O}_{2} \rightarrow \mathrm{CO}+\mathrm{HO}_{2}$

$\mathrm{HCO}+\mathrm{H} \rightarrow \mathrm{CO}+\mathrm{H}_{2}$

$\mathrm{CO}+\mathrm{OH} \rightarrow \mathrm{CO}_{2}+\mathrm{H}$

The specification together with physical and chemical characteristics of diesel, DME, and methanol are gathered in Table $4[4,29,30]$. The provided values for different fuels assist towards justification of performance, exergy, and flow behavior of blends.

Table 4. Alternative fuel properties [4, 29, 30]

\begin{tabular}{|c|c|c|c|}
\hline Properties & diesel & methanol & DME \\
\hline Chemical Formula & $\mathrm{C}_{14} \mathrm{H}_{25}$ & $\mathrm{CH}_{3} \mathrm{OH}$ & $\mathrm{CH}_{3} \mathrm{OCH}_{3}$ \\
\hline Molecular weight & 179 & 32.04 & 46.07 \\
\hline LHV (MJ/kg) & 42.5 & 20.0 & 28.43 \\
\hline A/F stoichiometric ratio (MJ/kg) & $14.7: 1$ & $6.43: 1$ & $9: 1$ \\
\hline Cetane number & 45.0 & 5.0 & $55-60$ \\
\hline Auto-ignition temperature, ${ }^{\circ} \mathrm{C}$ & 210 & 470 & 325 \\
\hline Dynamic viscosity (cSt) & $1-3.97$ & 0.543 & 0.185 \\
\hline Oxygen Content, $\mathrm{wt} \%$ & 0 & 49.93 & 35 \\
\hline
\end{tabular}


The fuels in the emulsified state have different combustive, kinetic, and chemical behavior than their pure composition. In the developed code, the calculation of LHV and the total energy of emulsions are estimated as:

$$
\begin{aligned}
& E_{t,(\text { Diesel-Methanol-DME })}=L H V_{\text {Diesel }} \times m_{\text {Diesel }}+L H V_{\text {Methanol }} \times m_{\text {Methanol }}+L H V_{D M E} \times m_{D M E} \\
& E_{t,(\text { Diesel-Methanol })}=L H V_{\text {Diesel }} \times m_{\text {Diesel }}+L H V_{\text {Methanol }} \times m_{\text {Methanol }} \\
& L H V_{t,(\text { Diesel-Methanol-DME })}=x_{\text {Diesel }} \times L H V_{\text {Diesel }}+x_{\text {Methanol }} \times L H V_{\text {Methanol }}+x_{D M E} \times L H V_{D M E} \triangleleft \\
& L H V_{t, \text { (Diesel-Methanol })}=x_{\text {Diesel }} \times L H V_{\text {Diesel }}+x_{\text {Methanol }} \times L H V_{\text {Methanol }} \text { (11) }
\end{aligned}
$$

where, $\mathrm{E}_{\mathrm{t}}$ represents total energy, $\mathrm{LHV}$ is the lower heating value of a specific fuel, $\mathrm{m}$ the fuel mass, and $\mathrm{x}$ the portion or percentage of fuel in the blend.

\subsection{Computation of exergy}

The key concept of second-law analysis is 'availability' (or exergy). The availability content of material represents its potential to do useful work. Unlike energy, exergy can be destroyed which is the result of such phenomena as combustion, friction, mixing, and throttling. The exergy balance in the cylinder can be formulated as follows [31]:

$$
\frac{d A_{c y l}}{d \phi}=\frac{\dot{m}_{\text {in }} b_{\text {in }}^{t m}-\dot{m}_{\text {out }} b_{\text {out }}^{\text {tm }}}{N}-\frac{d A_{l}}{d \phi}-\frac{d A_{w}}{d \phi}+\frac{d A_{f}}{d \phi}-\frac{d I}{d \phi}
$$

In the above equation, $\dot{m}_{\text {in }}$ and $\dot{m}_{\text {out }}$ are the incoming and outgoing flow rates, respectively, $b_{i n}^{t m}$ and $b_{\text {out }}^{\text {tm }}$ refer to their thermo-mechanical exergy which defines as follow $[31,32]:$

$$
b^{t m}=\left(h-h_{0}\right)-T_{0}\left(s-s_{0}\right)
$$


In Equation (12), $\frac{d A_{l}}{d \phi}$ represents the exergy of heat transfer to the cylinder walls on the basis of crank angle degree. It can be calculated as follow [31, 33]:

$$
\frac{d A_{l}}{d \phi}=\frac{d Q_{l}}{d \phi}\left(1-\frac{T_{0}}{T_{c y l}}\right)
$$

where, $\frac{d Q_{l}}{d \phi}$ is the heat transfer rate to the cylinder walls on the basis of crank angle degree and $T_{c y l}$ is the instantaneous temperature of the cylinder gasses, which are available from the engine simulation and energy analysis. In the exergy balance equation, the term of $\frac{d A_{w}}{d \phi}$ represents the indicated work transfer. In fact, it can be defined as the value of output exergy from the cylinder associated with the indicated work [31]:

$$
\frac{d A_{w}}{d \phi}=\left(P_{c y l}-P_{0}\right) \frac{d V}{d \phi}
$$

where $\frac{d V}{d \phi}$ states the rate of cylinder volume change based on crank angle degree and $P_{c y l}$ is the instantaneous cylinder pressure which both are calculable by the first law analysis in the engine processes. The burned fuel exergy on the crank angle basis can be calculated as following [31]:

$$
\frac{d A_{f}}{d \phi}=\frac{d m_{f b}}{d \phi} a_{f c h}
$$

where $a_{f c h}$ represents the chemical fuel exergy and for a blend composed of three different fuels this equation can be written as follow: 


$$
\frac{d A_{f}}{d \phi}=\frac{d m_{f b 1}}{d \phi} a_{f c h 1}+\frac{d m_{f b 2}}{d \phi} a_{f c h 2}+\frac{d m_{f b 3}}{d \phi} a_{f c h 3}
$$

The chemical exergy of substances in the environment (e.g. fuel, sulfur, combustion products such as $\mathrm{NO}$ or $\mathrm{OH}$, etc.) can be evaluated by considering an idealized reaction of the substance with others with the known chemical exergies [34]. This chemical exergy of the fuel can be expressed on a molar basis as follow [31, 34]:

$$
\bar{a}_{f c h}=\bar{g}_{f}\left(T_{0}, P_{0}\right)-\left(\sum_{p} x_{p} \bar{\mu}_{p}^{0}-\sum_{r} x_{r} \bar{\mu}_{r}^{0}\right)
$$

where index $p$ denotes products $\left(\mathrm{CO}_{2}, \mathrm{H}_{2} \mathrm{O}, \mathrm{CO}\right.$, etc.) and index $r$ is the reactants (fuel and $\mathrm{O}_{2}$ ) of the (stoichiometric) combustion process, $T_{0}$ and $P_{0}$ are the dead state temperature and pressure, and the over bar denotes properties on a mole basis. For liquid fuels of the general type $\mathrm{C}_{\mathrm{z}} \mathrm{H}_{\mathrm{y}} \mathrm{O}_{\mathrm{p}} \mathrm{S}_{\mathrm{q}}$, applicable in internal combustion engines, the chemical exergy of fuel can be expressed as follows (on a kg basis) [35]:

$$
a_{f c h}=\operatorname{LHV}\left(1.0401+0.01728 \frac{y}{z}+0.0432 \frac{p}{z}+0.2196 \frac{q}{z}\left(1-2.0628 \frac{y}{z}\right)\right)
$$

where $L H V$ is the fuel lower heating value.

The $\frac{d I}{d \phi}$ term in exergy balance equation represents the rate of irreversibility production in the cylinder, which includes combustion, viscous loss, turbulence, mixing, etc. According to Dunbar and Lior [36], a combustion reaction has four major sources of internal irreversibility. They are:

- A chemical diffusion process in which air and fuel molecules are drawn together.

- Combustion of the fuel-air mixture (thermo-chemical reaction). 
- Internal energy exchange through molecular collisions amongst the products and radiation heat transfer amongst product constituents due to unequal heat distribution.

- Mixing process whereby reactants mix before combustion, and products mix with reactants during combustion due to proximity.

Since the contribution of combustion in irreversibility production is more than $90 \%$ [37, 38 , in the present study, only the combustion irreversibility is taken to evaluate the incylinder irreversibilities. The combustion irreversibilities on the crank angle basis can be given as $[39,40]$ :

$$
\frac{d I}{d \phi}=-\frac{T_{0}}{T_{c y l}} \sum_{j} \mu_{j} \frac{d m_{j}}{d \phi}
$$

where subscript $j$ includes all reactants and products. For ideal gases, $\mu_{j}=g_{j}$ and for fuels

$$
\mu_{f}=a_{f c h}
$$

Aforementioned equations can be solved by the numerical methods in order to evaluate the second-law terms in an engine cycle.

\section{Results and discussion}

\subsection{Combustion and performance of the engine}

Fig. 4 demonstrates the variation trend of TKE for combustion of D50 and D80M20 blends under EGR of 0 and $20 \%$. As shown, the intensity of turbulence for the blend with lower diesel proportion (D50) presents higher TKE amount since an increase of DME and methanol fraction in the blend would increase the flammability of the mixture. The definition of turbulent kinetic energy that is estimated at the initial condition as: 
$T K E=\frac{3}{2} \times U^{\prime 2}\left[\frac{m^{2}}{s^{2}}\right]$

$U^{\prime}=0.25 \times(\bar{V})\left[\frac{m}{s}\right]$

$\bar{V}=\frac{2 \times N \times S}{60}\left[\frac{m}{s}\right]$

where, $\mathrm{N}$ denotes the engine speed, $\overline{\mathrm{V}}$ is the mean piston velocity, and $\mathrm{S}$ represents the stroke.

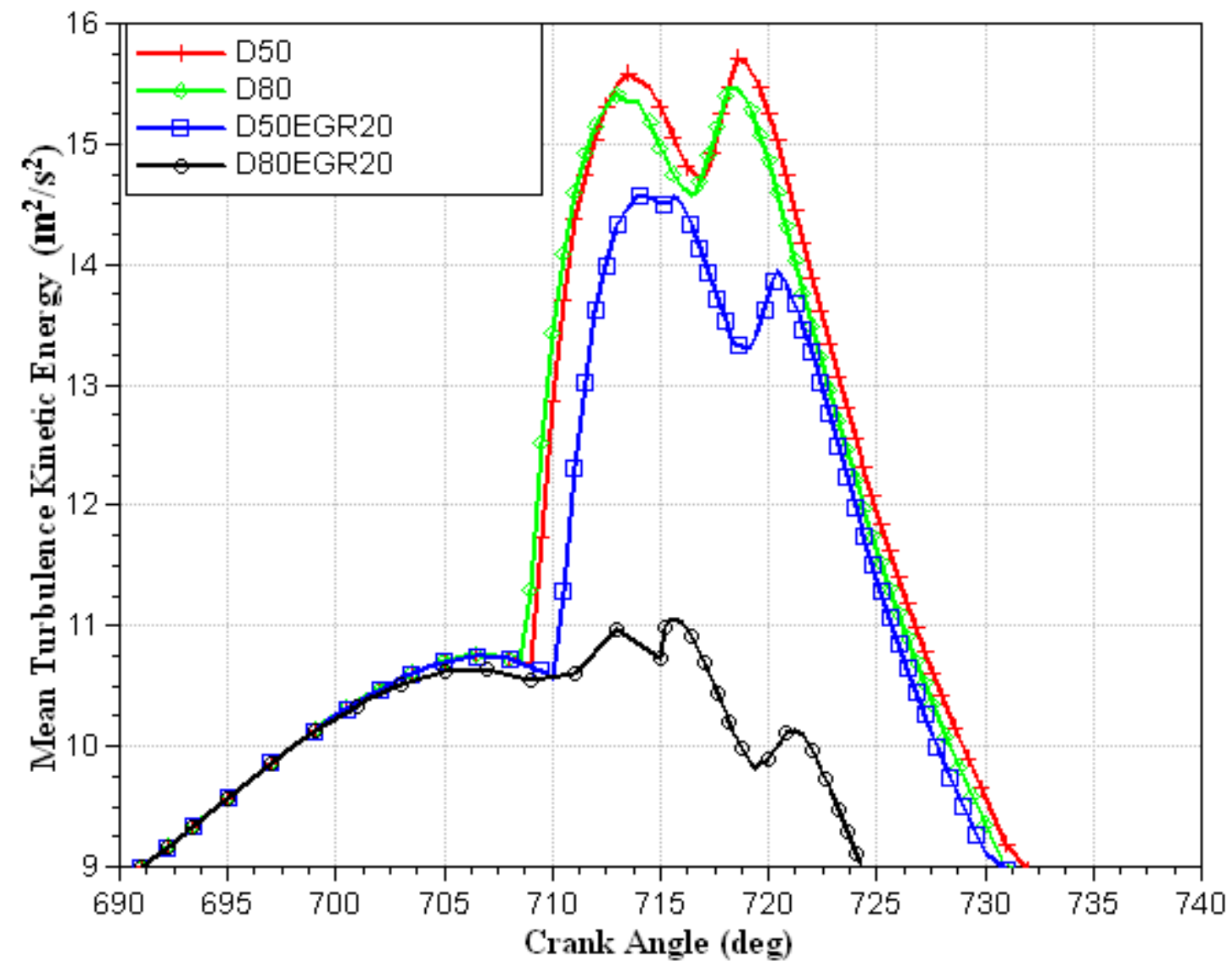

Figure 4. Variation of TKE vs. CA for high and low diesel fraction with/without EGR Regarding combustion characteristics, the pressure curves of fuel blends are provided in Fig. 5. It is apparent that changing fuel composition has a less significant role than EGR in in-cylinder pressure; in addition, an increase of diesel share in the blend would decline the 
pressure at late combustion phase, though the peak pressure is of D60 case. Based on the fuel specifications listed in Table 3, although the heating value of diesel is higher, because the viscosity of DME and methanol are lower, involvement of these alternative fuels would enhance spraying quality. Other reasons for outperformance of blended fuels with decrease of diesel attributes to an addition of oxygen in molecular bond and a balanced ratio of C$\mathrm{O}-\mathrm{H}$ in blend composition. The EGR incorporation makes a leaner mixture, which shifts the combustion towards expansion stroke, thus reducing the chamber pressure.

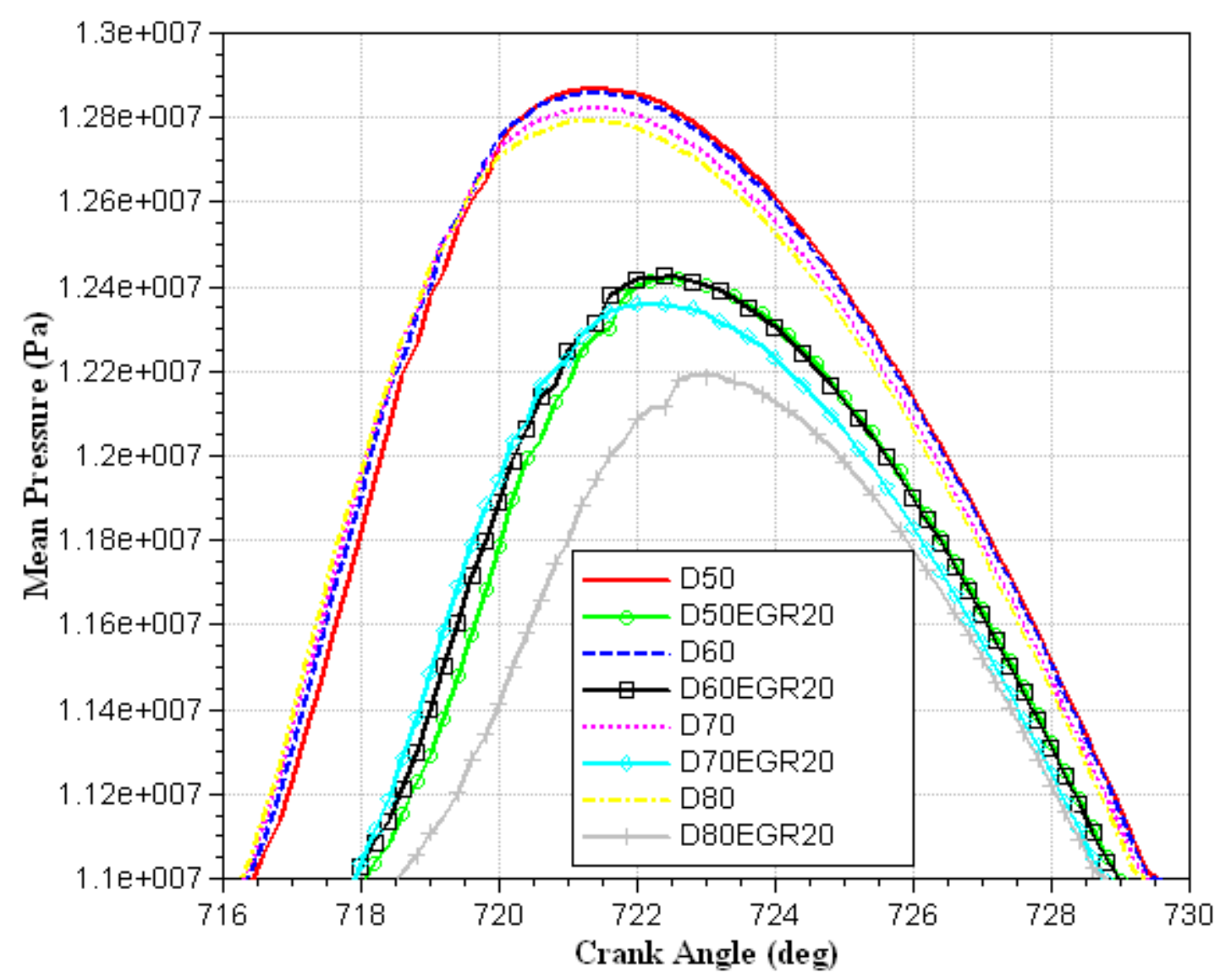

Figure 5. Pressure history of different blends vs. CA for various fuels with/without EGR 
In order to quantify the ignition and combustion quality of the compound fuels, two important parameters are employed as shown in Fig. 5 that are namely ignition delay (ID) and rate of pressure rise (RPR) for EGR $=0$ and $\mathrm{EGR}=20 \%$.

The RPR is calculated in 4 intervals step with central differencing derivatives:

$R P R=\frac{d P_{i}}{d \theta}=\frac{P_{i+2}-P_{i-2}}{4 h}$

$P$ denotes the discrete calculated pressure, $h$ is the change in CA step size between two consecutive runs, so in our case, $h=\Delta \alpha$.

According to Fig. 6a, in total, an increase in diesel share brings about a decreasing trend in ignition delay that can be explained by higher auto-ignition temperatures of replaced fuels i.e., DME and methanol (see Table 4). The max. RPR is plotted in Fig. $6 \mathrm{~b}$ for different fuel composition and EGR rates. In the presence of EGR addition, increasing diesel share led to higher RPR, while the contrary is happening for the case of no EGR application such that increasing the diesel in the compound fuel composition reduces the PRP. This illustrates that the replacement of diesel with DME and methanol as a three-component blend allows for better reaction with air to boost the pressure in the absence of EGR. The EGR can alleviate sudden pressure rise and knock probability of blends containing methanol and DME.

(a) 


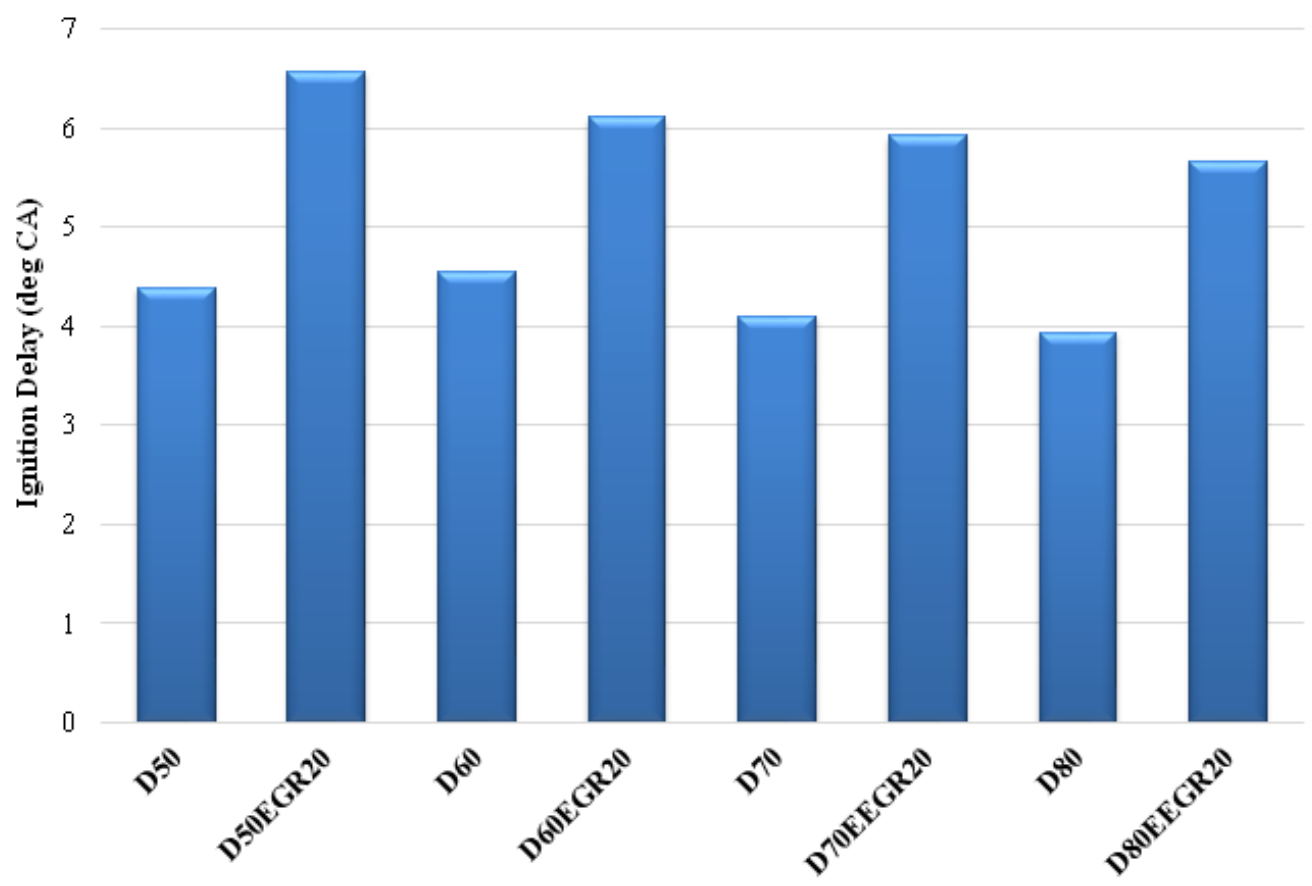

(b)

3.5

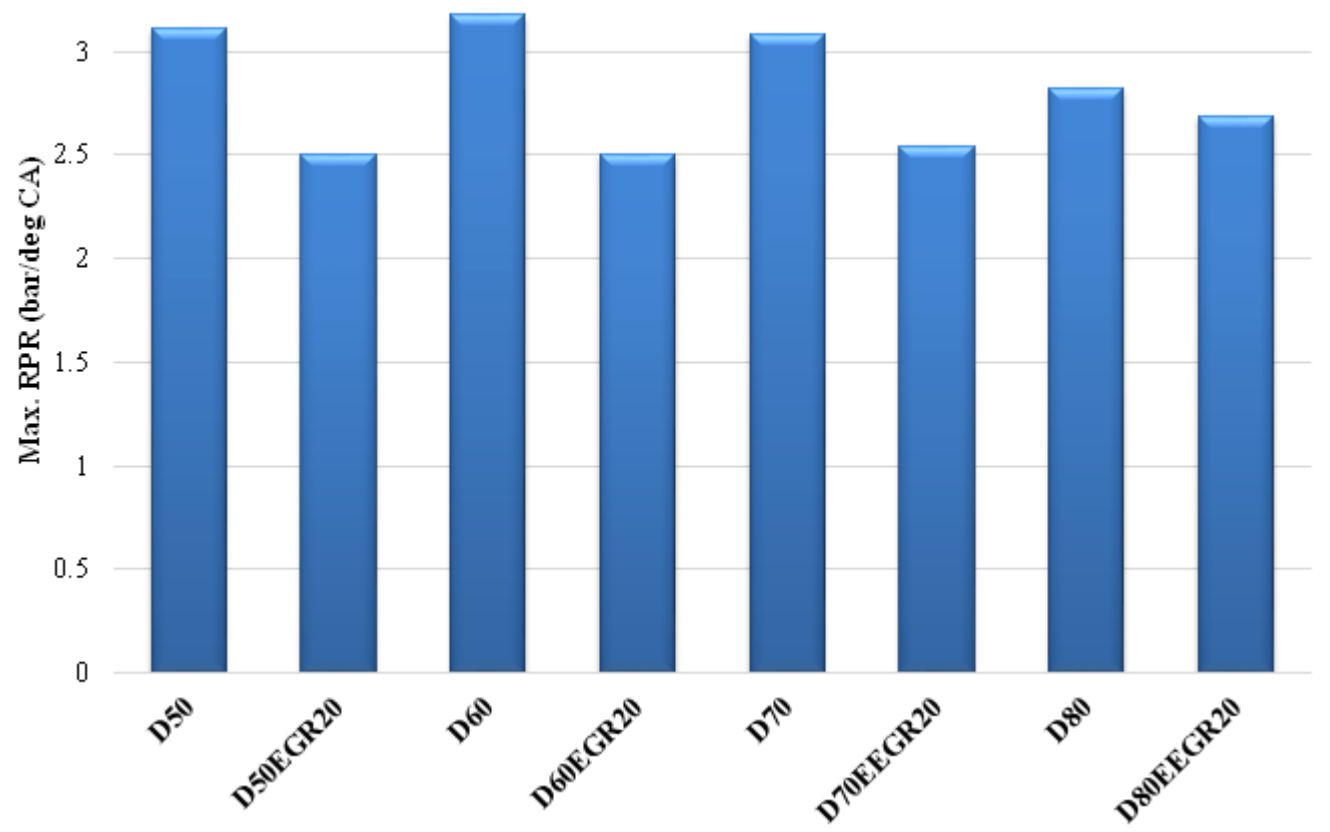


Figure 6. (a) Ignition delay for different blended fuel composition for EGR $=0$ and EGR $=20 \%$, (b) Max. RPR for different blended fuel composition for EGR $=0$ and EGR $=$

$$
20 \%
$$

Fig. 7 shows the HRR curves of different blended fuels for different operational modes. The peak HRR as seen belongs to D50 that as expected is in concordance with RPR results since this composition generated the highest-pressure jump and instantaneous heat generation due to oxygen involvement in the molecular structure of DME and methanol. The key point is that when EGR is included, the HRR of different blends shows different behavior, and D80M20 is dominant, while in the absence of EGR, the peak HRR reaches $59.49 \mathrm{~J} / \mathrm{deg}$ for D50.

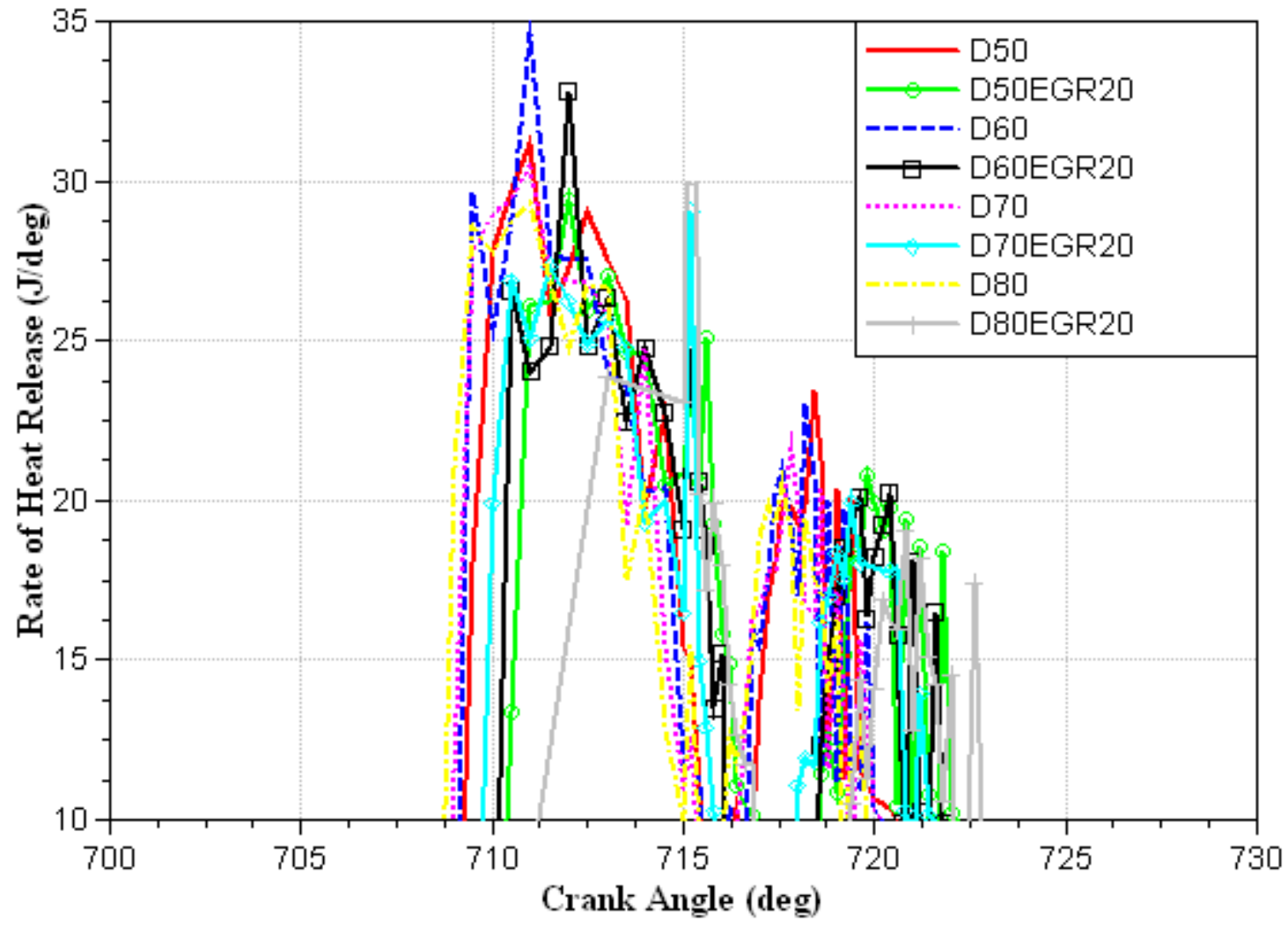

Figure 7. HRR curves vs. CA for different fuel blends with/without EGR 
For further illustration of heat generation of different multi-component fuels, Fig. 8 is presented. Again as shown in Fig. 8, the EGR $=20 \%$ application led to a significant decrease of AHR for all blended fuels and as diesel share decreases in the blend, the AHR increases as well. This is primarily because the methanol and DME are low-viscous liquids, which can be disintegrated easily and ameliorate the spray and mixing process. The secondary reason goes to high cetane number of DME (55-60), which improves the flammability and ignition index of the blend.

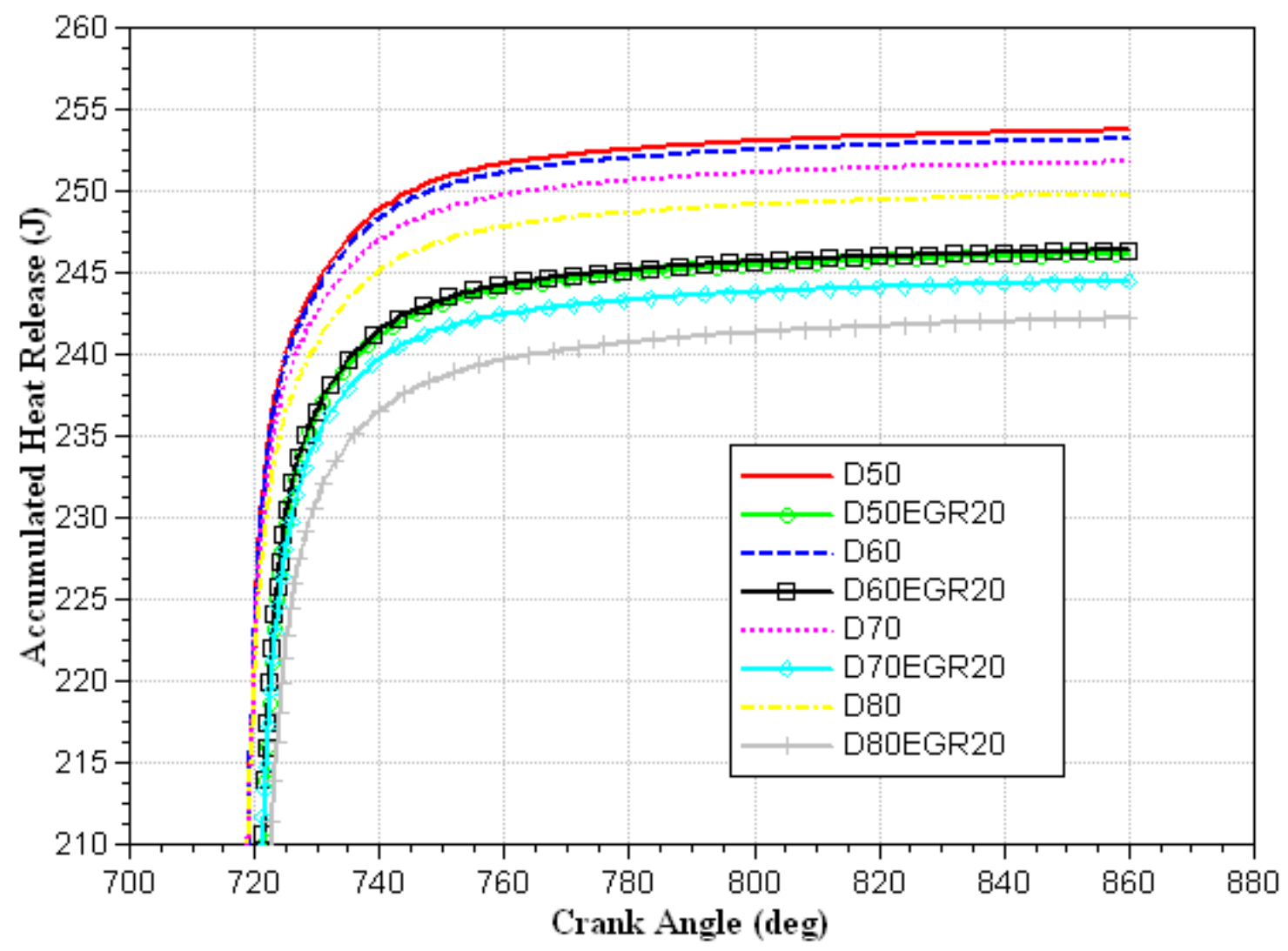

Figure 8. AHR of different blends vs. CA, various fuels with/without EGR

Another outstanding combustion parameter is the in-cylinder temperature that is plotted for EGR and without EGR consideration in Fig. 9. Due to the dilution effect of EGR, the temperature is dropped for all the fuels and increasing the diesel proportion (from D50 to D80M20) in the blend caused a slight decrease in the temperature. Moreover, adding 
methanol and DME increase the oxygen content, which will improve the oxidation of hydrocarbons and would definitely increase the chamber temperature.

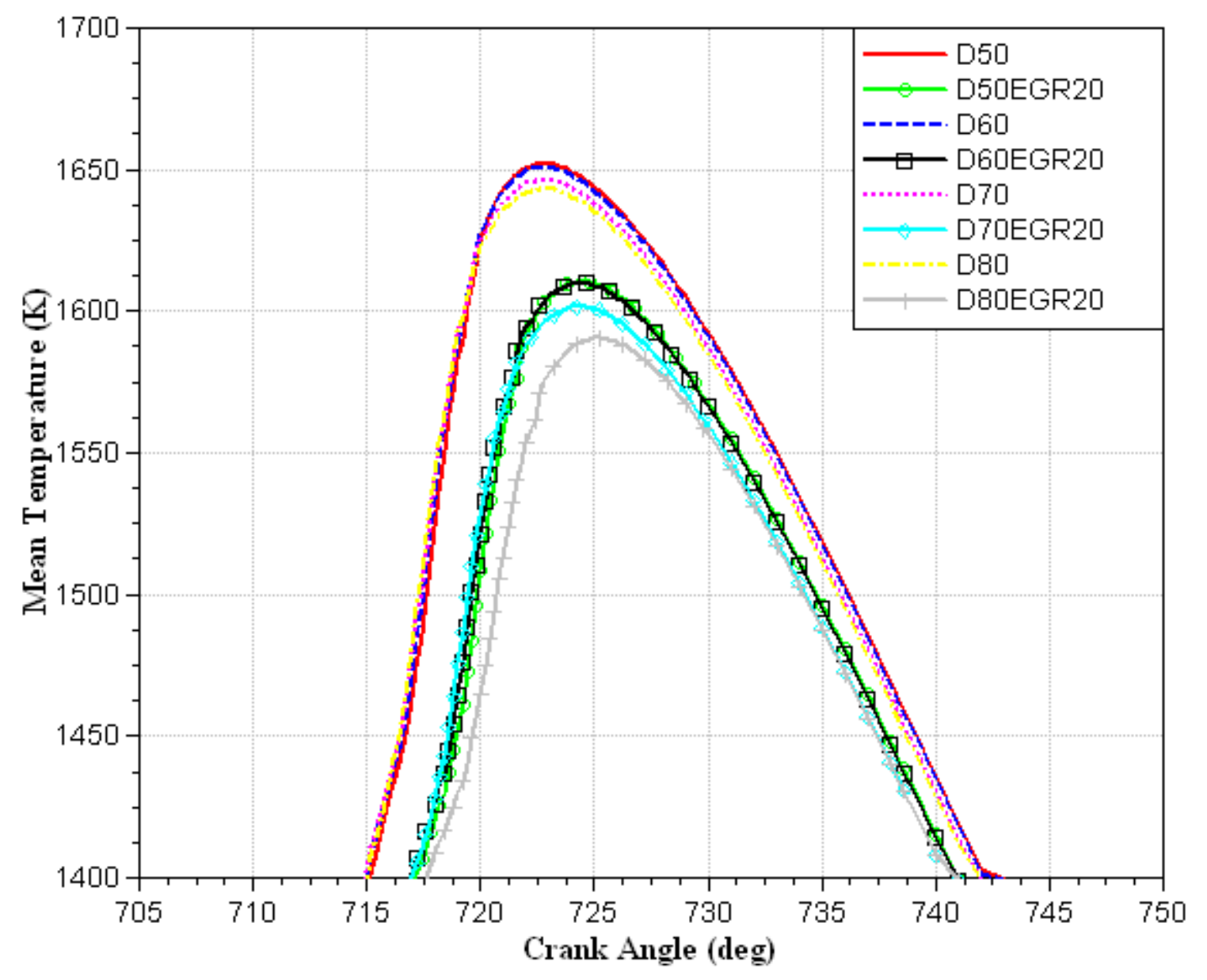

Figure 9. In-cylinder temperature vs. CA for different blends with/without EGR

The wall heat-flux diagram for different fuels and EGR effects is shown in Fig. 10. The minimum and maximum heat flux of the wall pertains to D80M20/EGR20 and D50 with 10855.5 W and $-13420.9 \mathrm{~W}$, respectively. The more heat-flux of D50 is associated with better spraying characteristics and inherent combustion qualities of blended fuel with more percentage of methanol and DME. 


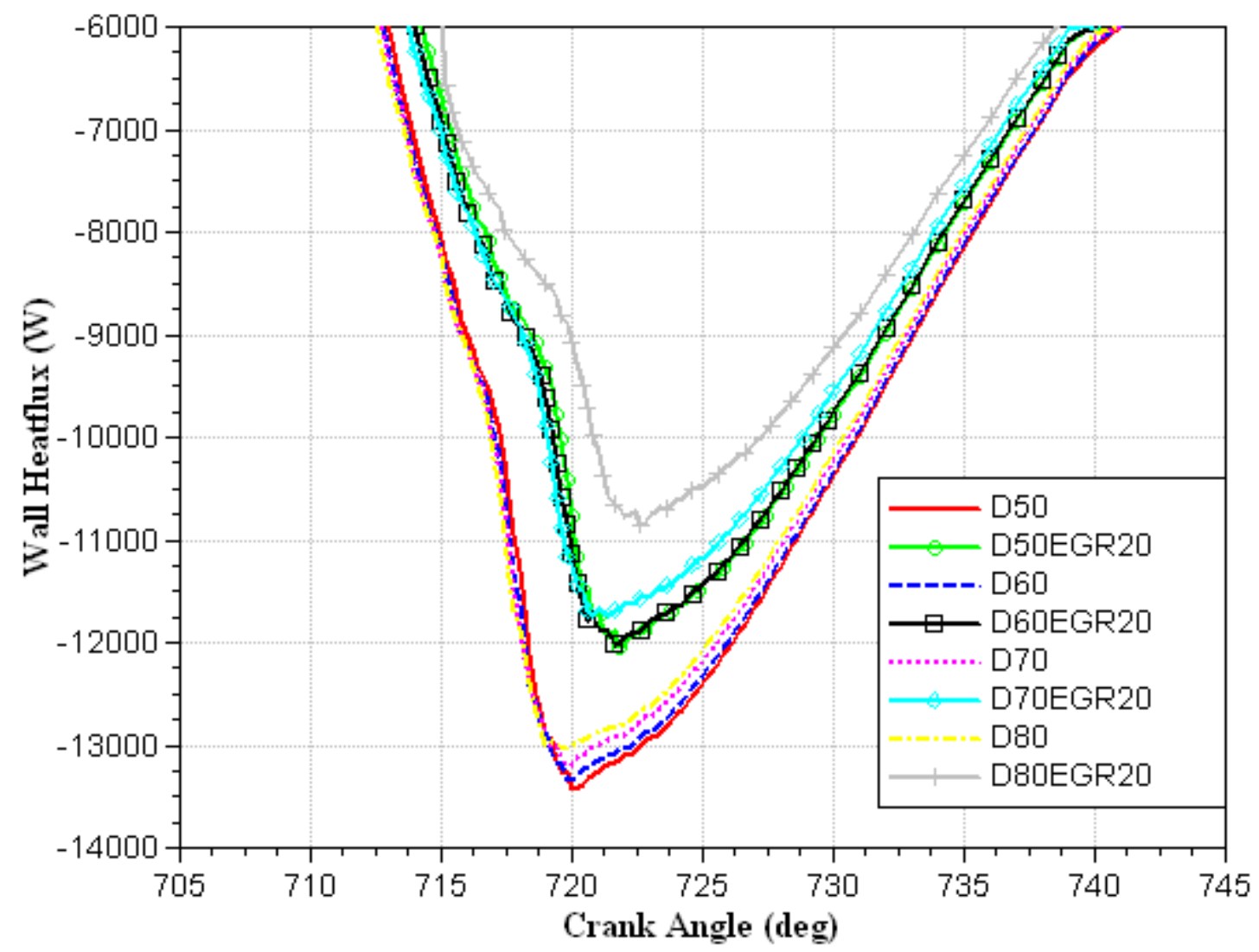

Figure 10. WHF vs. CA for different blends with/without EGR

Table 5 is provided to exhibit the performance and efficiency of HCCI engine for different fuel compositions under different engine speeds and EGR levels. First of all, it can be admitted that D50 with 35\% efficiency is the dominant blend as other performance metrics such as indicated power and indicated torque are also greater, since in-cylinder pressure and heat generation for it is sensibly superior than other blends. Second, for a given blend EGR as predicted would reduce the performance adversely and lead to a debilitated engine functionality as for D70, EGR=20\% has reduced IT from 18.41 N.m to 17.08 N.m. As the results indicate, the engine operation at low speed of $1400 \mathrm{rpm}$ would decrease the engine efficiency, although IT and IMEP increased for any of the blends. 
The NOx emission results are depicted in Fig. 11 with variable fuel composition during CA. It is evident that the low-concentration of NOx species occurs with D80 since this blend produces lower heat and results in lower in-cylinder temperature. Besides, the thermal NOx based on the Zeldovich mechanism, the oxygen concentration in the chamber is important as well. Therefore, D50 is a blend whose combustion produces more NOx since the combined effect of thermal NOx and oxygen concentration is more sensible for this particular blend. It can be observed that DME and methanol have oxygen in their molecular structure, which can give way to higher NOx amount after combustion.

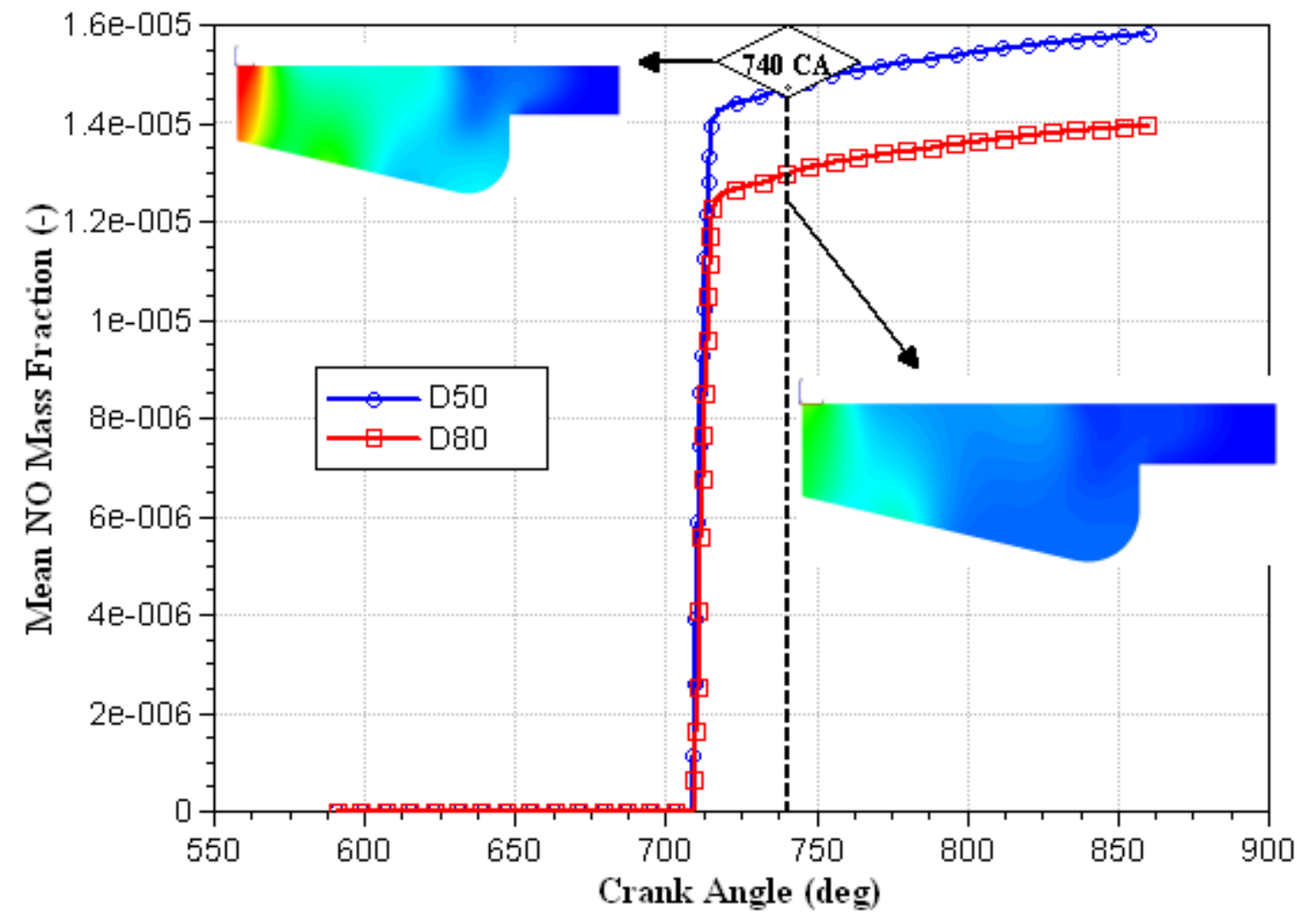

Figure 11. NO variation vs. CA for different blends 
Table 5. Performance of HCCI for blended multi-component fuels at rated engine speeds

\begin{tabular}{|c|c|c|c|c|c|c|c|c|c|c|c|c|}
\hline & \multicolumn{8}{|c|}{$\mathrm{N}=2000 \mathrm{rpm}$} & \multicolumn{4}{|c|}{$\mathrm{N}=1400 \mathrm{rpm}$} \\
\hline & 号 & ஜ & $\stackrel{\circ}{\stackrel{0}{n}}$ & $\stackrel{\circ}{\circ}$ & 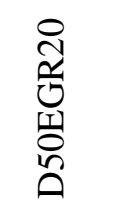 & 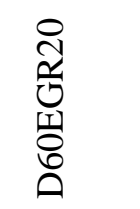 & 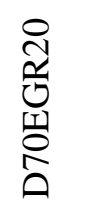 & 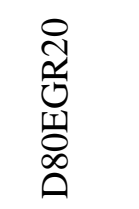 & n. & $\stackrel{\infty}{\circ}$ & 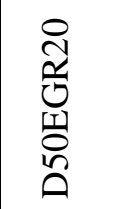 & 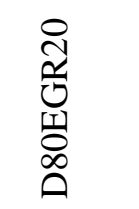 \\
\hline $\begin{array}{l}\text { IMEP } \\
\text { (bar) }\end{array}$ & 7.6 & 7.57 & 7.52 & 7.48 & 7.36 & 7.32 & 7.26 & 7.21 & 7.87 & 7.77 & 7.75 & 7.64 \\
\hline \begin{tabular}{|l|} 
IP \\
$(\mathrm{kW})$
\end{tabular} & 3.95 & 3.92 & 3.85 & 3.81 & 3.68 & 3.65 & 3.58 & 3.52 & 2.97 & 2.89 & 2.88 & 2.79 \\
\hline \begin{tabular}{|l} 
IT \\
(N.m)
\end{tabular} & 18.87 & 18.69 & 18.41 & 18.2 & 17.59 & 17.39 & 17.08 & 16.83 & 20.23 & 19.71 & 19.65 & 19.06 \\
\hline$\eta(\%)$ & $35 \%$ & $34.40 \%$ & $34 \%$ & $33.60 \%$ & $32.87 \%$ & $32.55 \%$ & $32 \%$ & $31.70 \%$ & $26.30 \%$ & $25.60 \%$ & $25.40 \%$ & $24.30 \%$ \\
\hline
\end{tabular}

\subsection{Exergy and irreversibility evaluation}

Availability of blended fuel energy in HCCI mode is a critical topic that has close ties with chemistry and combustion kinetics. The sources of irreversibilities when various fractions of fuel burnt can give an insight on exergy destruction factors. Fig. 12 exhibits the thermomechanical and accumulative irreversibility graphs with $\mathrm{CA}$ for different blends composition. On account of higher pressure and temperature curves for D50, higher thermo-mechanical exergy is seen for this case and EGR acts as a factor to reduce the power density. The increment of oxygenated methanol and DME fuels leads to complete oxidation and release of more chemical energy. This leads to combustion prolonging and the exhaust gases' thermo-mechanical exergy increment as can be seen in Fig. 12 a. 
For irreversibility, the highest and lowest amounts belong to D80 and D60, respectively. According to Eq. 20, there are three significant parameters, which have a dominant influence on the combustion irreversibility including in-cylinder gases temperature, chemical exergy, and the combustion rate. One of the key parameters, which affect irreversibility, is the chemical exergy of fuels. The chemical exergy of fuel is directly related to its LHV and according to Table 4, diesel fuel has the highest LHV and chemical exergy, followed by DME and methanol. Therefore, D80 with the highest amount of diesel in its composition and the lowest in-cylinder temperature has the highest amount of irreversibility.

(a)

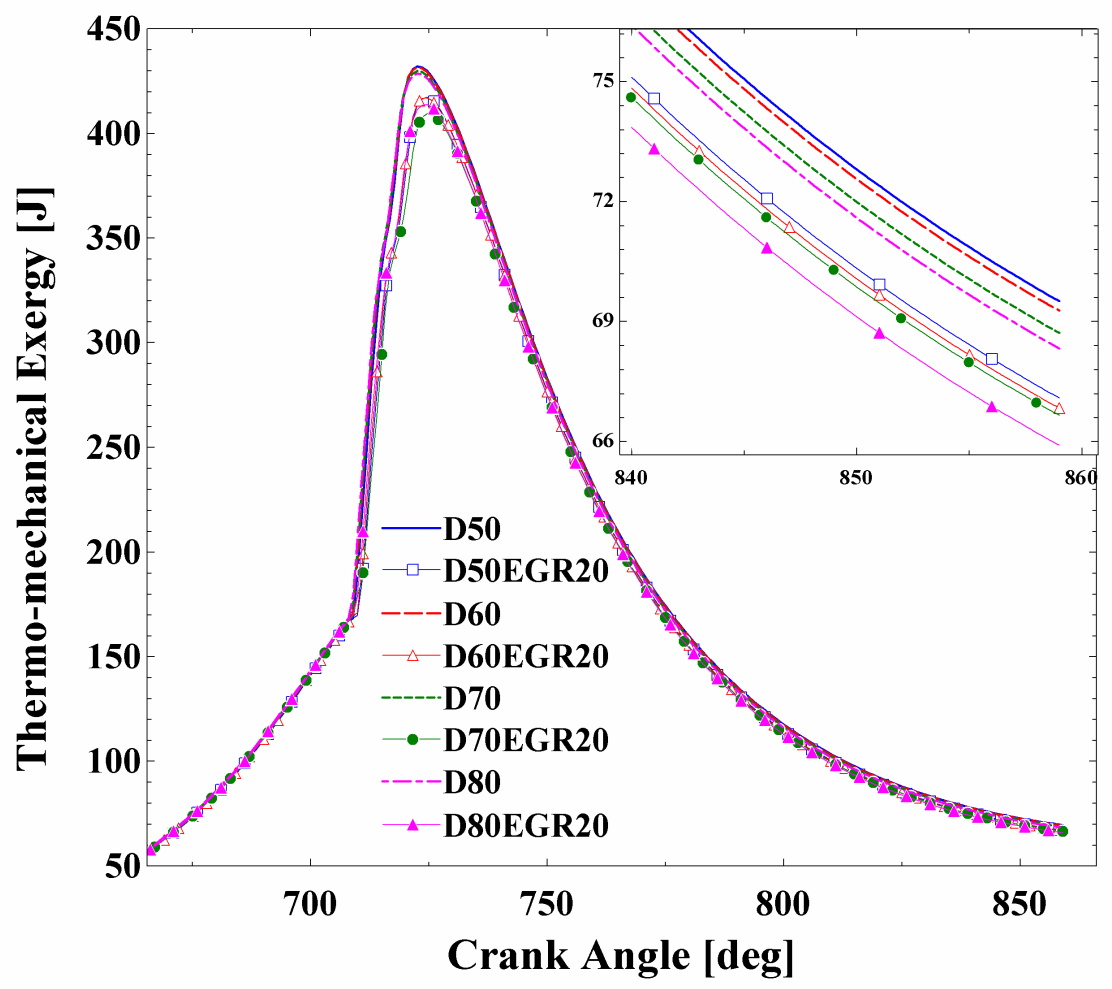

(b) 


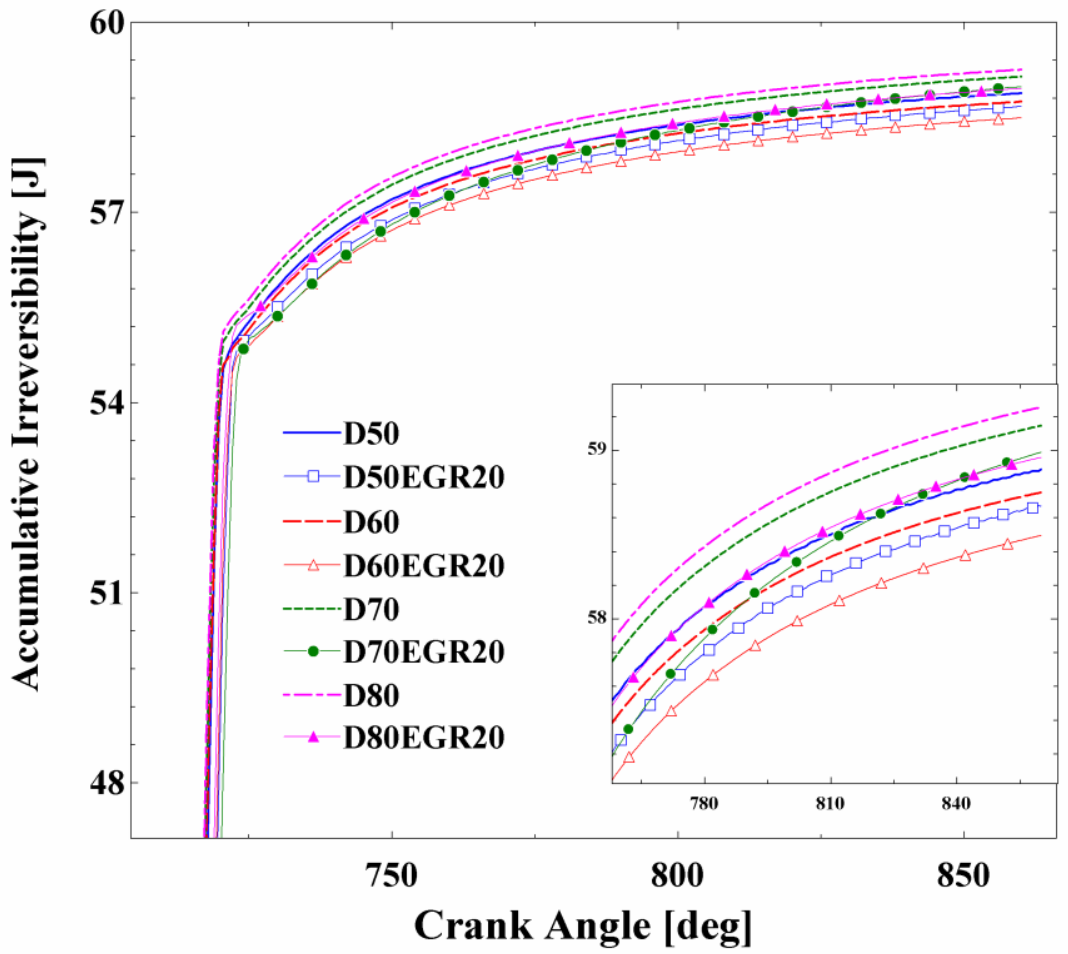

Fig. 12 (a) thermo-mechanical exergy and (b) accumulative exergy for different blends and exergy

Two main exergy parameters including heat loss exergy and indicated work exergy reduced to burned fuel exergy (as a percentage of burned fuel exergy) are represented in Fig. 13. Based on Fig. 13 a., the heat loss exergy for the cases with 0\% EGR is higher than that of cases with $20 \%$ EGR. The lowest heat loss exergy reduced to fuel exergy belongs to D80EGR20 with $10.68 \%$. As seen in this figure, the percentage of heat loss exergy for D50 is lower than those of D60, D70, and D80. This is because, despite the wall heat flux for D50 is higher than others (according to Fig. 10), but the burned fuel exergy for this blend is higher which leads to this trend. As seen in Fig. 13 b, the cases with $20 \%$ EGR have higher indicated work exergy reduced to burned fuel exergy than the cases without EGR. The main reason for this trend is lower burned fuel exergy due to incomplete combustion in the presence of EGR despite the higher indicated work exergy in the cases without EGR. 
This means the cases with EGR transfer higher portion of burned fuel exergy as indicated work.

(a)

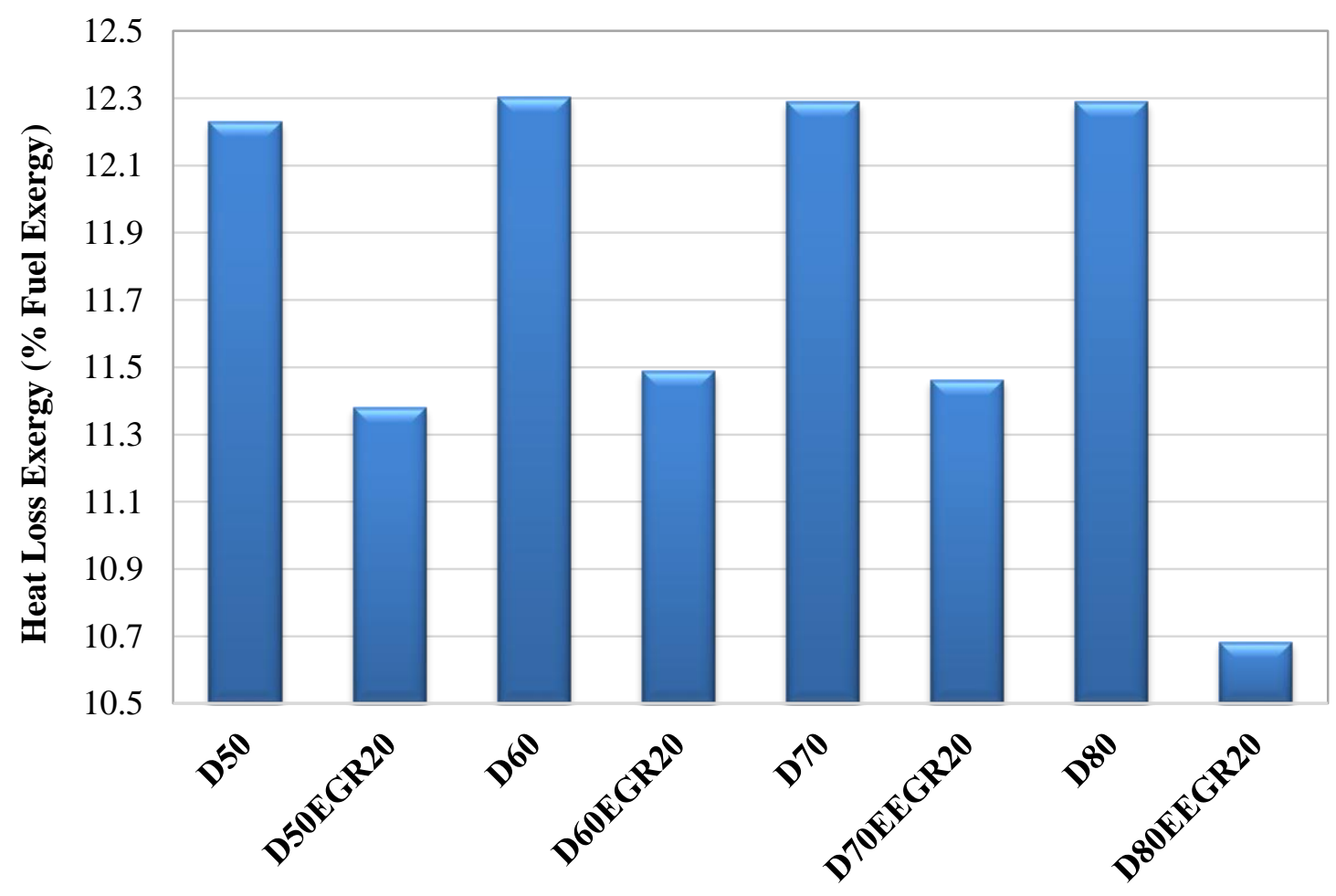

(b) 


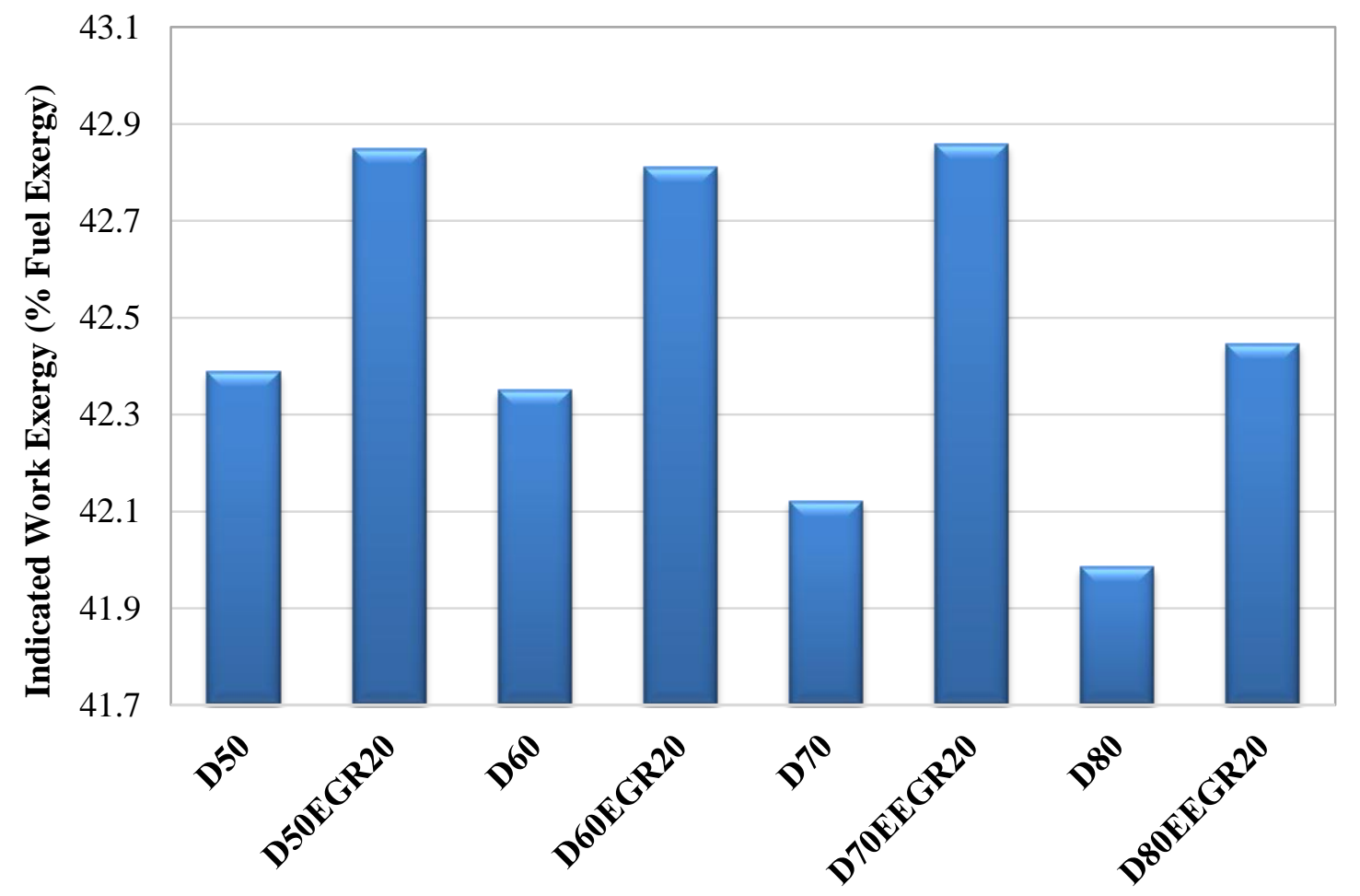

Fig. 13 Variation of (a) heat loss exergy and (b) indicated work exergy reduced to burned fuel exergy for different blend composition and EGR rates

A key parameter, known as exergetic performance coefficient, is taken into account recently to evaluate the energy performance and exergy output simultaneously. Calculation of this index is given as:

$E P C=\frac{\text { Indicated } W o r k}{\text { Irreversibility }}$

In the above correlation, there is a competition between output indicated work (determined by heating value and mean effective pressure) with irreversibility (determined by the degree of combustion). The best compromise can be reached for D60 as plotted in Fig. 14. In other words, D60 has more total exergy and exhibits the lowest irreversibility, as a result, the EPC fraction is the highest for D60 case. 


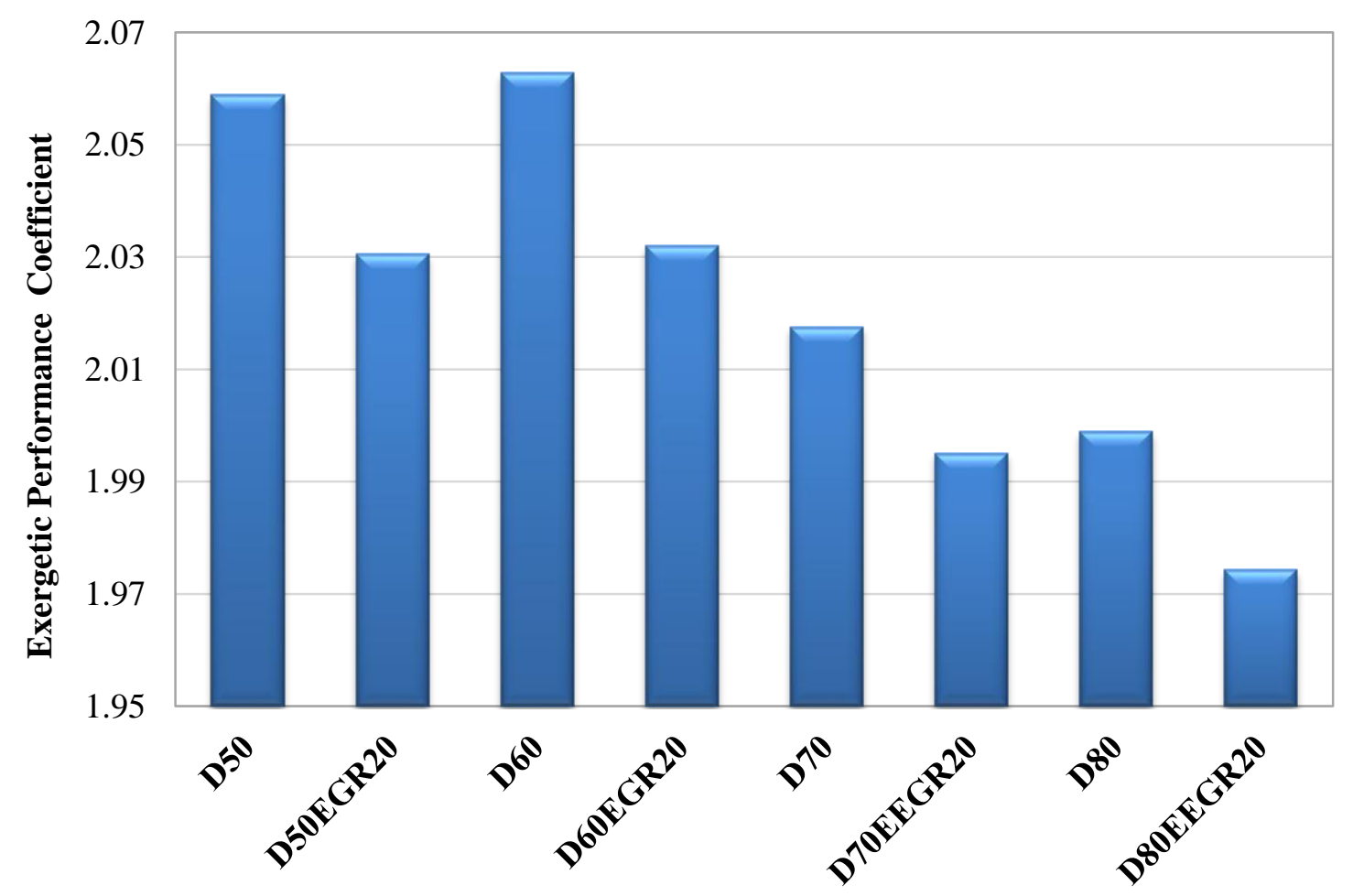

Fig. 14 Variation of EPC for different blend composition and EGR rates

\section{Conclusion}

It is of great interest to concoct and synthesize fuel blends that can cope with the demand to both increase the engine power and reduce the emission at the same time. This study investigated four fuel blends of D50M30DME20, D60M10DME30, D70M20DME10, and D80M20 in an HCCI engine for with/without EGR application. As the following remarks would confirm, D50M30DME20 is an ideal solution to boost the energetic performance, while D60M10DME30 dominates in terms of exergy performance and lower irreversibility:

i. The D50 powered HCCI engine with EGR $=20 \%$ has the maximum ID and minimum RPR, while increasing diesel fraction in blend decreases ID monotonically and increases RPR. When no EGR is used, D60 (representative of highest DME fraction in the blend) has both maximum ID and RPR. It shows 
that EGR alters the pattern of ID and RPR trends for proposed multicomponent fuels.

ii. Due to higher cetane number of DME $(\sim 60)$, the blend with the highest ratio percentage of DME (D60) represents the highest ID (4.546 CA) and RPR (3.177 bar/deg CA), which results in high HRR. These are owing to the low viscosity of DME and longer ID, which remarkably improves the mixture uniformity. When EGR is involved, the scale of intense burning rate for this blend is suppressed.

iii. The case of D60 has the lowest irreversibility rate and ranks second in exergy terms that leads to identifying it with the highest EPC. On the other hand, D80 with the highest portion of diesel fuel in its composition (80\%), shows the worst energetic and exergetic performance among the blends.

iv. It was revealed that in engine performance terms (IMEP, IP, IT, efficiency), D50 among other blends is dominant in both $1400 \mathrm{rpm}$ and $2000 \mathrm{rpm}$ speeds. As known EGR would decrease the engine's performance and efficiency and higher engine speed definitely increases the engine output power. The closure statement is that there found a potential candidate solution (i.e. D50 powered HCCI engine) that can simultaneously increase the engine efficiency and decrease the irreversibility.

\section{References}

[1] Sorenson, S.C., Glensvig, M. and Abata, D.L., 1998. Dimethyl ether in diesel fuel injection systems (No. 981159). SAE Technical Paper. 
[2] Soni, D.K. and Gupta, R., 2017. Application of nano emulsion method in a methanol powered diesel engine. Energy, 126, pp.638-648.

[3] De Caro, P.S., Mouloungui, Z., Vaitilingom, G. and Berge, J.C., 2001. Interest of combining an additive with diesel-ethanol blends for use in diesel engines. Fuel, 80(4), pp.565-574.

[4] Park, S.H. and Lee, C.S., 2014. Applicability of dimethyl ether (DME) in a compression ignition engine as an alternative fuel. Energy Conversion and Management, 86, pp.848863.

[5] Arcoumanis, C., Bae, C., Crookes, R. and Kinoshita, E., 2008. The potential of dimethyl ether (DME) as an alternative fuel for compression-ignition engines: A review. Fuel, 87(7), pp.1014-1030.

[6] Liu, M.B., He, B.Q. and Zhao, H., 2015. Effect of air dilution and effective compression ratio on the combustion characteristics of a HCCI (homogeneous charge compression ignition) engine fuelled with n-butanol. Energy, 85, pp.296-303.

[7] Chen, Y., Wolk, B., Mehl, M., Cheng, W.K., Chen, J.Y. and Dibble, R.W., 2017. Development of a reduced chemical mechanism targeted for a 5-component gasoline surrogate: a case study on the heat release nature in a GCI engine. Combustion and Flame, 178, pp.268-276.

[8] Maurya, R.K. and Akhil, N., 2016. Numerical investigation of ethanol fuelled HCCI engine using stochastic reactor model. Part 2: Parametric study of performance and emissions characteristics using new reduced ethanol oxidation mechanism. Energy Conversion and Management, 121, pp.55-70. 
[9] Li, G., Zhang, C. and Zhou, J., 2017. Study on the knock tendency and cyclical variations of a HCCI engine fueled with n-butanol/n-heptane blends. Energy conversion and management, 133, pp.548-557.

[10] Turkcan, A., Altinkurt, M.D., Coskun, G. and Canakci, M., 2018. Numerical and experimental investigations of the effects of the second injection timing and alcoholgasoline fuel blends on combustion and emissions of an HCCI-DI engine. FUELGUILDFORD-, 219(1), pp.50-61.

[11] Zhang, J., Huang, Z. and Han, D., 2018. Exergy losses in auto-ignition processes of DME and alcohol blends. Fuel, 229, pp.116-125.

[12] Wang, Z., Liu, H., Ma, X., Wang, J., Shuai, S. and Reitz, R.D., 2016. Homogeneous charge compression ignition (HCCI) combustion of polyoxymethylene dimethyl ethers (PODE). Fuel, 183, pp.206-213.

[13] Yousefzadeh, A. and Jahanian, O., 2017. Using detailed chemical kinetics 3D-CFD model to investigate combustion phase of a CNG-HCCI engine according to control strategy requirements. Energy conversion and management, 133, pp.524-534.

[14] Nishi, M., Kanehara, M. and Iida, N., 2016. Assessment for innovative combustion on HCCI engine by controlling EGR ratio and engine speed. Applied Thermal Engineering, 99, pp.42-60.

[15] Khandal, S.V., Banapurmath, N.R. and Gaitonde, V.N., 2019. Performance studies on homogeneous charge compression ignition ( $\mathrm{HCCI}$ ) engine powered with alternative fuels. Renewable Energy, 132, pp.683-693. 
[16] Godiño, J.A.V., Aguilar, F.J.J.E. and García, M.T., 2018. Simulation of HCCI combustion in air-cooled off-road engines fuelled with diesel and biodiesel. Journal of the Energy Institute, 91(4), pp.549-562.

[17] Yao, C., Pan, W. and Yao, A., 2017. Methanol fumigation in compression-ignition engines: A critical review of recent academic and technological developments. Fuel, 209, pp.713-732.

[18] Xu, G.L., Yao, C.D. and Rutland, C.J., 2014. Simulations of diesel-methanol dualfuel engine combustion with large eddy simulation and Reynolds-averaged Navier-Stokes model. International Journal of Engine Research, 15(6), pp.751-769.

[19] Neshat, E., Saray, R.K. and Hosseini, V., 2016. Investigation of the effect of reformer gas on PRFs HCCI combustion based on exergy analysis. International Journal of Hydrogen Energy, 41(7), pp.4278-4295.

[20] Nemati, P., Jafarmadar, S. and Taghavifar, H., 2016. Exergy analysis of biodiesel combustion in a direct injection compression ignition (CI) engine using quasi-dimensional multi-zone model. Energy, 115, pp.528-538.

[21] Amjad, A.K., Saray, R.K., Mahmoudi, S.M.S. and Rahimi, A., 2011. Availability analysis of n-heptane and natural gas blends combustion in HCCI engines. Energy, 36(12), pp.6900-6909.

[22] K. Hanjalic, M. Popovac, M. Hadziabdic, A robust near-wall elliptic-relaxation eddyviscosity turbulence model for CFD, Int. J. Heat Fluid Flow 25 (2004) 1047-1051.

[23] Colin, O. and Benkenida, A., 2004. The 3-zones extended coherent flame model (ECFM3Z) for computing premixed/diffusion combustion. Oil \& Gas Science and Technology, 59(6), pp.593-609. 
[24] Ebrahimi, R. and Desmet, B., 2010. An experimental investigation on engine speed and cyclic dispersion in an HCCI engine. Fuel, 89(8), pp.2149-2156.

[25] Mansoury, M., Jafarmadar, S., Talei, M. and Lashkarpour, S.M., 2017. Optimization of HCCI (Homogeneous Charge Compression Ignition) engine combustion chamber walls temperature to achieve optimum IMEP using LHS and Nelder Mead algorithm. Energy, 119, pp.938-949.

[26] Zang, R., Yao, C., Yin, Z., Geng, P., Hu, J. and Wu, T., 2016. Mechanistic study of ignition characteristics of diesel/methanol and diesel/methane dual fuel engine. Energy \& Fuels, 30(10), pp.8630-8637.

[27] Assanis, D.N., Filipi, Z.S., Fiveland, S.B. and Syrimis, M., 2003. A predictive ignition delay correlation under steady-state and transient operation of a direct injection diesel engine. Journal of Engineering for Gas Turbines and Power, 125(2), pp.450-457.

[28] Westbrook, C.K. and Dryer, F.L., 1979. Comprehensive mechanism for methanol oxidation. Combustion Science and Technology, 20(3-4), pp.125-140.

[22] Varol, Y., Öner, C., Öztop, H.F. and Altun, Ş., 2014. Comparison of methanol, ethanol, or n-butanol blending with unleaded gasoline on exhaust emissions of an SI engine. Energy Sources, Part A: Recovery, Utilization, and Environmental Effects, 36(9), pp.938-948.

[29] Park, S.H. and Lee, C.S., 2013. Combustion performance and emission reduction characteristics of automotive DME engine system. Progress in Energy and Combustion Science, 39(1), pp.147-168.

[30] Soni, D.K. and Gupta, R., 2016. Optimization of methanol powered diesel engine: A CFD approach. Applied Thermal Engineering, 106, pp.390-398. 
[31] Haywood, R.W., Equilibrium thermodynamics for engineers and scientists, 1980.

[32] Taghavifar, H., Nemati, A., Salvador, F.J. and De la Morena, J., 2019. Improved mixture quality by advanced dual-nozzle, included-angle split injection in HSDI engine: Exergetic exploration. Energy, 167, pp.211-223.

[33] Nemati, A., Barzegar, R. and Khalilarya, S., 2015. The effects of injected fuel temperature on exergy balance under the various operating loads in a DI diesel engine. Int. J. Exergy, 17(1), pp.35-53.

[34] Bejan, A., 2016. Advanced engineering thermodynamics. John Wiley \& Sons.

[35] Stepanov, V.S., 1995. Chemical energies and exergies of fuels. Energy, 20(3), pp.235242.

[36] Dunbar, W.R. and Lior, N., 1994. Sources of combustion irreversibility. Combustion Science and Technology, 103(1-6), pp.41-61.

[37] Rakopoulos, C.D. and Giakoumis, E.G., 2006. Second-law analyses applied to internal combustion engines operation. Progress in energy and combustion science, 32(1), pp.2-47. [38] Alkidas, A.C., 1988. The application of availability and energy balances to a diesel engine. Journal of Engineering for Gas Turbines and Power, 110(3), pp.462-469.

[39] Nemati, A., Fathi, V., Barzegar, R. and Khalilarya, S., 2013. Numerical investigation of the effect of injection timing under various equivalence ratios on energy and exergy terms in a direct injection SI hydrogen fueled engine. international journal of hydrogen energy, 38(2), pp.1189-1199.

[40] Rakopoulos C.D., Andritsakis E.C. DI and IDI Diesel Engines Combustion Irreversibility Analysis. 1993 American Society of Mechanical Engineers-Winter Annual Meeting, New Orleans, Louisiana, U.S.A., 1993. pp. 17-32 


\section{Abbreviation (alphabetical)}

AHR: accumulated heat release $(\mathrm{J})$

ATDC: after top dead center

BD: biodiesel-diesel

B50D50: 50\% biodiesel, 50\% diesel shares by volume

CA: crank-angle

D100: pure diesel

D50: Diesel(50\%)Methanol(30\%)DME(20\%)

D60: Diesel(60\%)Methanol(10\%)DME(30\%)

D70: Diesel(70\%)Methanol(20\%)DME(10\%)

D80: Diesel(80\%)Methanol(20\%)

DME: Dimethyl ether

$\mathrm{E}_{\mathrm{t}}$ : total energy

ECFM-3Z: extended coherent flame method-3 zone

ED: ethanol-diesel

EGR: exhaust gas recirculation

EPC: exergetic performance coefficient

EVO: exhaust valve opening

HRR: heat release rate $(\mathrm{J} / \mathrm{deg})$

HCCI: homogenous charge compression ignition

ID: ignition delay (deg CA)

IMEP: indicated mean effective pressure (bar)

IP: indicated power $(\mathrm{kW})$ 
IT: indicated torque (N.m)

IVC: injection valve closing

LHV: lower heating value $(\mathrm{MJ} / \mathrm{kg})$

RPR: rate of pressure rise (bar/deg)

TKE: turbulent kinetic energy $\left(\mathrm{m}^{2} / \mathrm{s}^{2}\right)$

$\overline{\mathrm{V}}:$ mean piston velocity $(\mathrm{m} / \mathrm{s})$

$\eta$ : efficiency 